\title{
Stability evaluation of hazardous translational slide zones in part of Yamunotri Pilgrimage route, National Highway 507, Uttarakhand, India
}

\author{
Suraj Prashad Bhatta ${ }^{1, *}$, Divya Dudeja ${ }^{2}$ and Ajay Kumar Biyani ${ }^{2}$ \\ ${ }^{1}$ Geo Mineral Reserves Private Limited, Kanchanpur, Nepal \\ ${ }^{2} \mathrm{DBS}(P G)$ College, Dehradun, India \\ ${ }^{*}$ Corresponding author's email: drsurajbhatt@gmail.com
}

\begin{abstract}
Slope failure is a widespread phenomenon in Lesser Himalaya owing to its fragile tectonic settings, rugged topography, high relief, abruptly varying gentle to steep slopes and peculiar climatic conditions. Road development and urban expansion have further deteriorated the slope conditions. National Highway 507, a part of the pilgrimage route to Yamunotri in Uttarakhand, is one such route, experiencing hostility from frequent slope failure episodes that are causing havoc for villagers and pilgrims. In the present study, the four most hazardous translational slide zones in the $22 \mathrm{~km}$ stretch from Judo to Kandi village in the Yamunotri pilgrimage route has been identified, for detailed geotechnical investigation and slope stability assessment applying different approaches. The rock masses of this region are inherently weak owing to their closeness to Aglar fault and other joints and fractures. Rock mass classification systems are used to assess the stability and for estimating strength parameters, viz. cohesion and angle of internal friction, essential for the factor of safety determination. They are slightly varying due to the relatively homogeneous grain size distribution and mineralogical composition of rock masses. Kinematic Analysis differentiated the type of failure as planar or wedge and, accordingly, factor of safety is determined by limit equilibrium approach. The factor of safety, computed strength parameters, discontinuity and slope properties, varies from 5.9 to 1.1 in dry conditions while it reduces below unity as the saturation upsurges. It depicts stable conditions in dry conditions but water penetration and saturation along the cracks and discontinuities during rainfall make them unstable. Close vicinity with fault, steep slope, presence of joints and weathered lithology are dominating factors initiating the instability in route with further aggravation by rainfall, road widening and urban expansion.
\end{abstract}

Keywords: Rock mass rating; Slope mass rating; Kinematic analysis; Factor of safety

Received: 8 March, 2021 Received in revised form: 19 June, 2021 Accepted: 23 June, 2021

\section{INTRODUCTION}

Fragile tectonic settings, rugged undulated topography, high relief, abruptly varying gentle to steep slopes, and peculiar climatic conditions make the Himalayan region vulnerable to frequent slope failures while infrastructural development without proper engineering considerations increases their occurrences and threats manifold.

Slope instability can occur naturally by major disasters such as earthquake, flash floods, cloudbursts etc. and can be aggravated by haphazard and unplanned construction. Kedarnath tragedy of year 2013 demonstrates the disaster driven slope instability. In this fatal event, heavy rainfall and massive cloudburst surged flash floods and large-scale landslides, bringing heavy death toll. Only within Bhagirathi-GangaNayar valley, about 1034 numbers of landslides occurred after the Kedarnath disaster (Pradhan et al., 2020). Sometimes, landslides can also initiate a huge disaster as happened recently on February 7, 2021 in Chamoli district of Uttarakhand, when a landslide at the terminus of the glacier (at an altitude of 5600 m) is known to trigger the snow avalanche and flash floods in the downstream of Rishiganga river. These flash floods covered Dhauliganga- Rishiganga and Alaknanda rivers and washed away five bridges leaving about 56 people dead and at least 150 people missing in the affected areas. Two power projects named Tapovan-Vishnugad hydel project and the Rishi Ganga hydel project, were also extensively damaged (ToI, 2021). Triggered either naturally by disasters or by anthropogenic intervention, slope failure can cause huge economic loss, environmental loss and several casualties, directly or indirectly.

Infrastructural development for hydropower projects, adornment of tourist places, road connectivity and widening, presently is increasing by leaps and bounds in this fragile tectonic entity with several challenges. Hence, in recent times, slope instability has become more prominent in hilly terrains (Singh et al., 2014; Umrao et al., 2011). Himalayan fragility with anthropogenic intervention in the form of inadequate and unplanned excavation of slopes for construction purpose provides a fatal combination degrading the stability. However, developmental activities are need 
of the day and cannot be avoided.

National Highway 507 (earlier called as NH 123) in Lesser Himalaya is part of the Yamunotri pilgrimage route in Uttarakhand and runs along Yamuna River. It is one such route bearing the prolonged hostility from frequent slope failure episodes, further aggravated recently by road construction, and widening. Blockage of route poses obstruction in traffic flow and daily supply to villagers. Pilgrims are stranded for days and suffer considerably. Yamunotri pilgrimage is one of the Char dhams religiously accredited among Hindu devotees and is situated $5 \mathrm{~km}$ downstream of a small lake named Saptrishi Kund. This lake is the source of River Yamuna located at an elevation of $4421 \mathrm{~m}$ on Kalindi Parbat. Yamuna River in its whole journey of $1376 \mathrm{~km}$, up to Prayagraj where it merges with the holy river Ganga has been tapped by many ongoing and proposed hydropower projects. Near Lakhwar village, a $204 \mathrm{~m}$ high concrete gravity dam is proposed for the generation of $300 \mathrm{MW}$ power using a gross available head of $178 \mathrm{~m}$. Activation of slides near dam sites can inflict economic loss as delay in construction, large expenditure on remedial measures. Emergencies arise not only as a result of slope failures in the immediate vicinity of the dam but large slides can dam river valleys upstream, creating impounded lakes. The life of the reservoir can also be reduced due to the increased sedimentation rate by the collapse of the slopes within a dam. Sudden collapse can even cause the formation of high waves in the reservoir beyond the crest of the dam (Gorbushina, 1997).

Since the path is a part of the important pilgrimage route and embracing a proposed site of hydropower project as well, the slope stability analysis are crucially necessary and undertaken to prevent any blockages in National Highway and for the safety of the proposed project. Hence, the present study deals with the slope stability evaluation of the $22 \mathrm{~km}$ stretch from village Judo to village Kandi in National Highway 507, Uttarakhand, by means of limit equilibrium method and rock mass classification systems. Kinematic analysis is also done to understand the possible mode, direction and geometry of failures with respect to discontinuities and slope.

Numerous researches have been done on the slope stability of hilly terrains by means of conventional and numerical techniques. Through kinematic analysis, which represents the interrelationship of the slope with discontinuities, the type of failure can be identified and the stability is done as per the type of failure (Ambrosi et al., 2006; Brideau et al., 2006). Analytical approach as limit equilibrium method (Zhu et al., 2003; Hammouri et al., 2008), and finite element method (Kanungo et al., 2013; Pain et al., 2014; Verma et al., 2016). Additionally, the extensively active methods for stability investigations in used are: i) empirical approach as rock mass rating (Taherniya et al., 2014; Abbas et al., 2015; Romana et al., 2015; Mondal et al., 2016; Regmi et al., 2016), ii) neural network (Ermini et al., 2005); statistical (Carrara et al., 1991; Chung et al., 1995; Jade et al., 1993; Li \& $\mathrm{Xu}, 2016$ ), iii) GIS based (Chand, 2011; Singh et al., 2020) and iv) analysis using charts (Hoek et al., 1981; Shen et al., 2013; Eid, 2014). Slope instability depends upon a number of parameters associated with slope, discontinuity, lithology, meteorology, weathering and others (Hoek and Bray, 1981; Harp et al. 1990; Reeuwijk 1993; Wieczorek 1996; Iverson 2000; Pradhan et al., 2011 \& 2014; Ahmad et al., 2013; Springman et al., 2013; Joshi \& Rajan, 2018).

Noteworthy work dealing with slope stability issues in the Uttarakhand region has been carried out by various researchers (Anbalagan, 1997; Anbalagan et al., 2007; Sarkar, 2012a; Kanungo, 2013) while some site specific studies were conducted (Naithani, 2007; Singh et al., 2014; Dudeja et al., 2017). Anbalagan et al. (1992; 2008) and Sarkar et al., (2012a) evaluated comprehensively many slopes in Uttarakhand Himalaya using rock mass rating (RMR), slope mass rating (SMR) and other empirical methods and created many modifications in these methods as per Himalayan setting. The present study area is still unexplored with respect to geotechnical features of slope materials and consequent slope instability.

\section{PHYSIOGRAPHY AND GEOLOGY OF AREA}

The $22 \mathrm{~km}$ route lies between $77^{\circ} 54^{\prime}-78^{\circ} 10^{\prime}$ longitude and $30^{\circ} 28^{\prime}-30^{\circ} 35^{\prime}$ latitude (Survey of India toposheet no $53 \mathrm{~F} / 14$ and $53 \mathrm{~J} / 2$ in 1:50000 scale), and is the part of National Highway 507 that approaches Barkot from Vikasnagar and covers Lohari, Lakhwar and Khera villages in Dehradun and Tehri Garhwal districts of Uttarakhand (Fig. 1).

The area is characterized by steep slopes, randomly trending hills and dissected into narrow to widely open Yamuna River valleys developed by the meandering river system. Both depositional and erosional terraces have been recognized in the study area. The developments of depositional terraces at different levels describe for the successive changes in the course of Yamuna River and witnessed the effect of upliftment.

Generally, NNE to SSW flowing Yamuna River takes a sudden turn towards the west near the Yamuna Bridge and joined with Aglar River flowing in EW direction. Its course is nearly straight, guided by a strike-slip Aglar Fault. Dendritic, trellis, sub-parallel to parallel drainage pattern is observed (Fig. 2).

Humid to sub-temperate climatic conditions exist in the area with average annual rainfall range from 200 


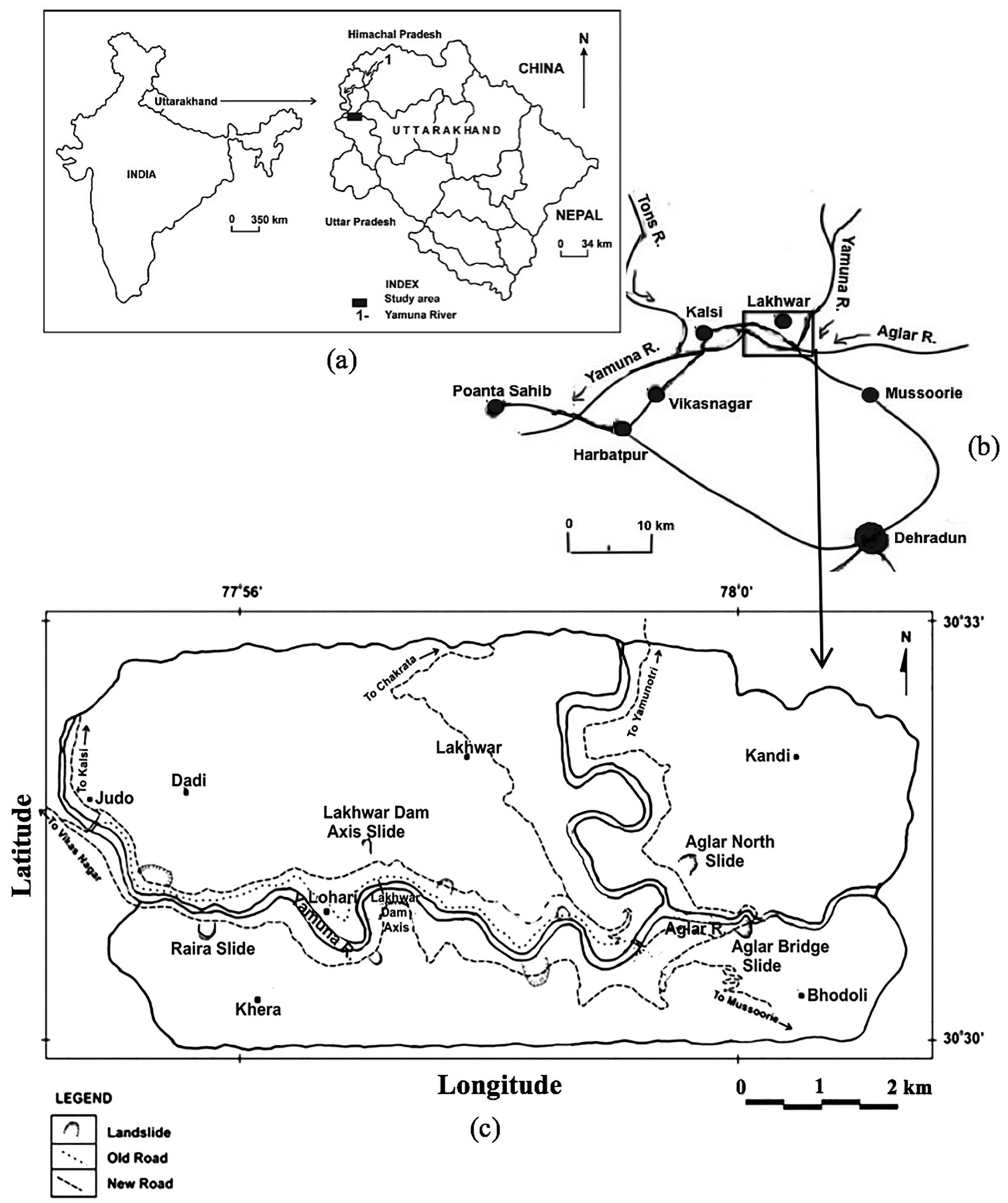

Fig. 1: (a) \& (b) Location map of study area (c) Slide distribution of the study area

to $300 \mathrm{~cm}$ while temperature is varying from 40 to $5{ }^{\circ} \mathrm{C}$. An amount of $85 \%$ of total annual rainfall is received during June to September, the months of July and August being the wettest.

Geologically, the route lies in Lesser Himalaya: one of the most structurally complex litho-tectonic units of Himalaya. Lithostratigraphic units of Krol Nappe including Mandhali, Chandpur and Nagthat formations of Jaunsar group and Blaini, Krol and Tal formations of Mussoorie group. Around the slide zones, Chandpur, Nagthat and Blaini formations are encountered (Fig. 3). Chandpur Formation, consisting of greenish grey phyllite and phyllitic slates with inter bedded bands of dirty brown fine-grained quartzite, has uniform lithology throughout the study area (Fig. $4 \mathrm{a}, \mathrm{b})$. The exposed slates and phyllites are thinly foliated, folded and friable. About $800 \mathrm{~m}$ wide sill of dolerite, is intruded in Chandpur Formation near Lakhwar Dam site (Fig. 4f). Dolerite exposed is partially weathered, greenish grey to dark green in colour and fine- to coarse-grained. Criss-cross quartz, calcite and feldspar veins of about 1 to $15 \mathrm{~cm}$ thick are common in this sill. The rocks are highly jointed with three to four prominent sets of joints. Nagthat Formation (Fig. 4c, e) comprising of brownish white, 


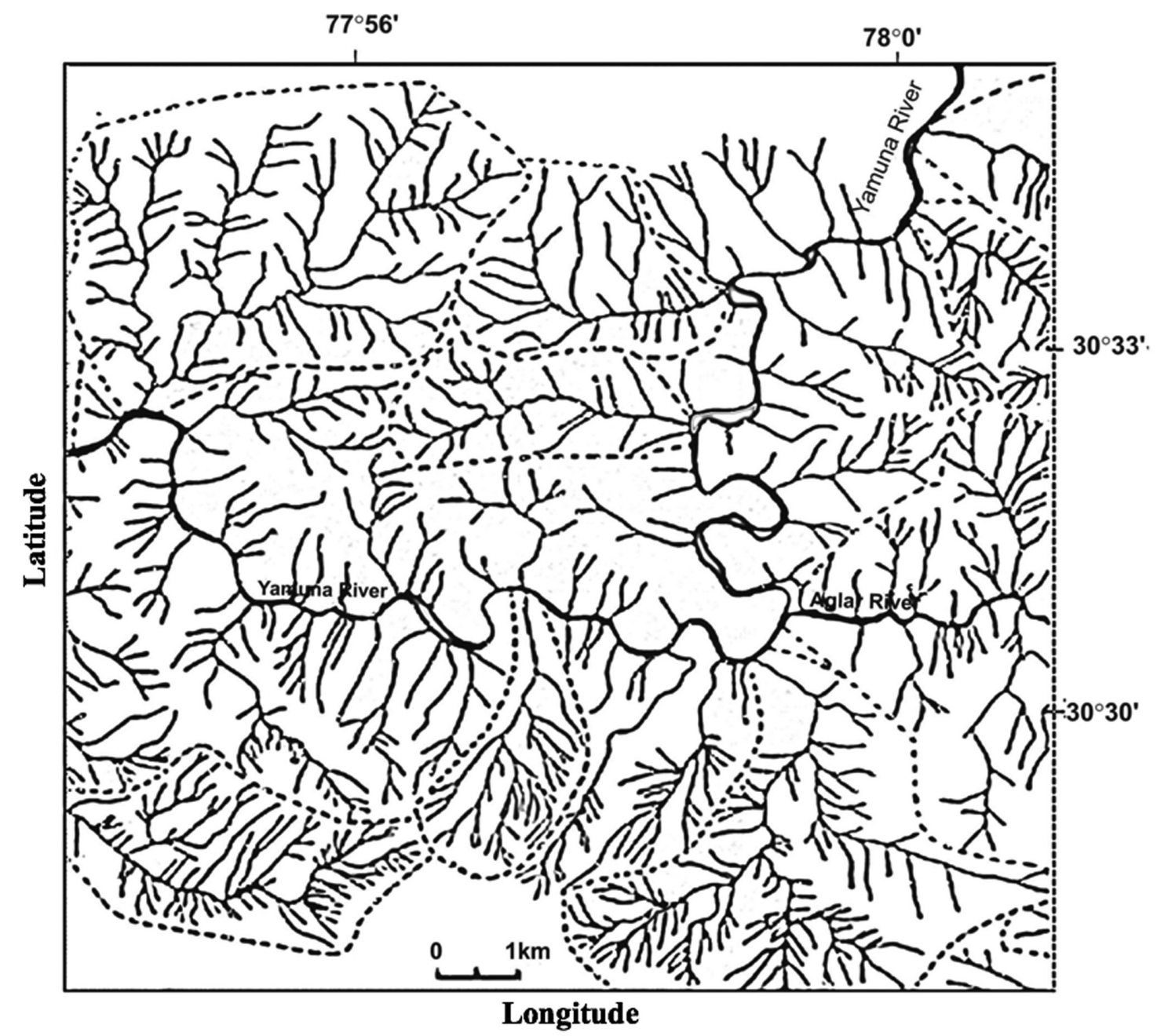

Fig. 2: Drainage map of study area (dotted lines mark the boundaries of basin).

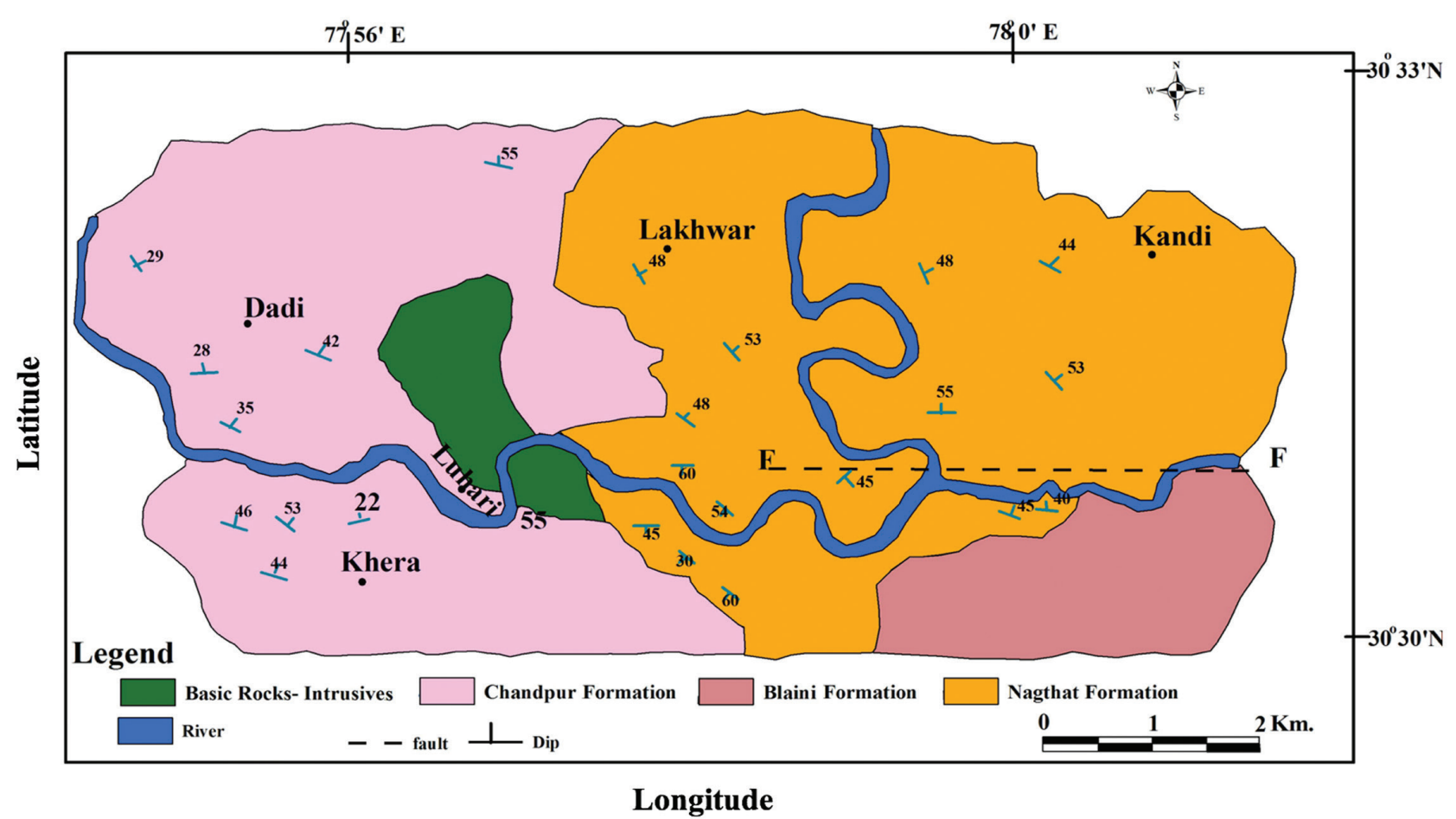

Fig. 3: Geological map of study area (after Valdiya, 1980). 
pink and light grey coloured, fine-grained quartzite having thick coating of limonite along bedding and joints (Fig. 4d) succeed Chandpur Formation (Valdiya, 1980).

The westerly flowing, Aglar River joins with the Yamuna River at a place called Yamuna Bridge. Aglar draining the limestones and slates of the Krol
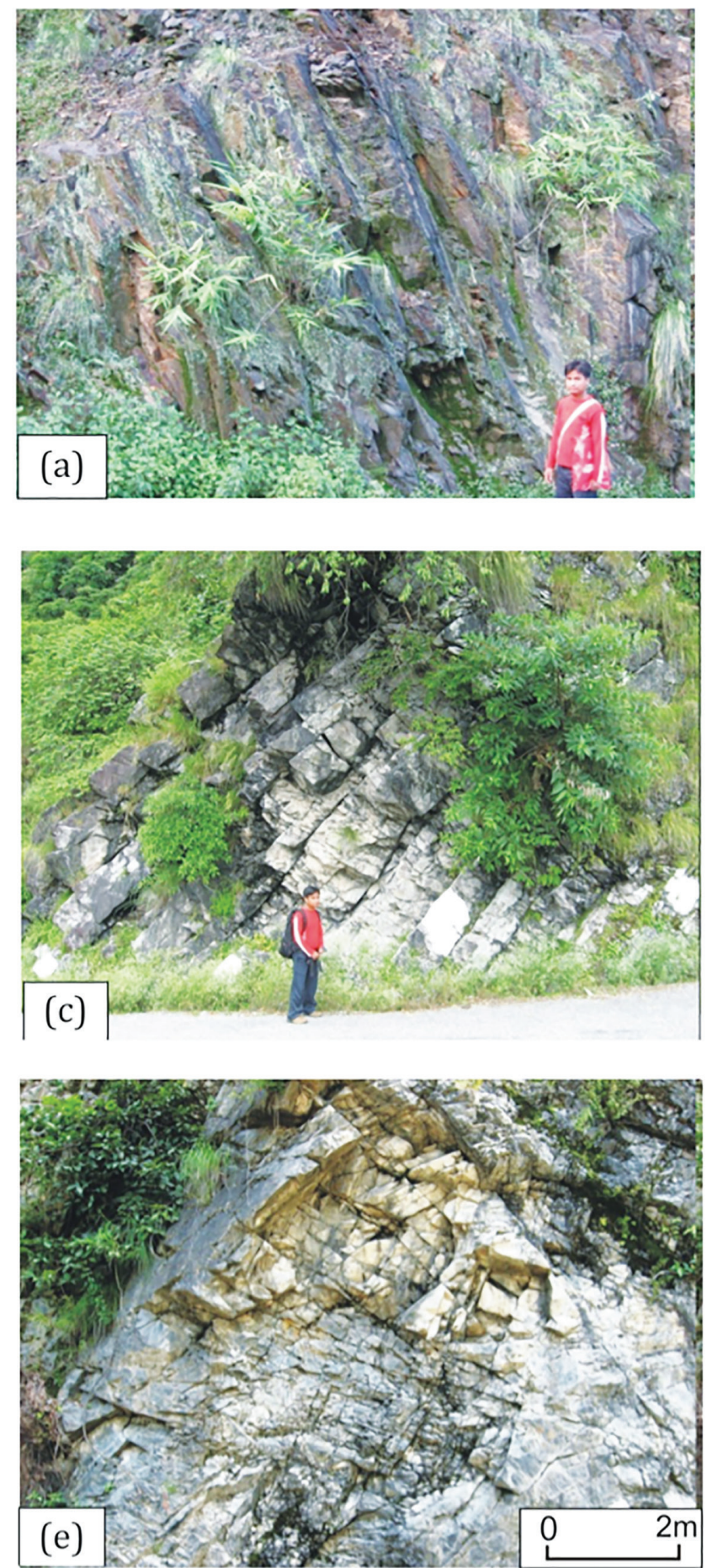

Formation in the northern slopes of the Mussorie Ridge and conglomerates, grey phyllitic slates, carbonaceous pyritous slate of the Blaini Formation. Aglar River flows along the axis of one of the anticlines. A lineament is well marked along the Aglar River mainly between Lakhwar and Marga in the west and east respectively. The lineament is regarded to be a fault termed as Aglar fault. It is recognized as E-W
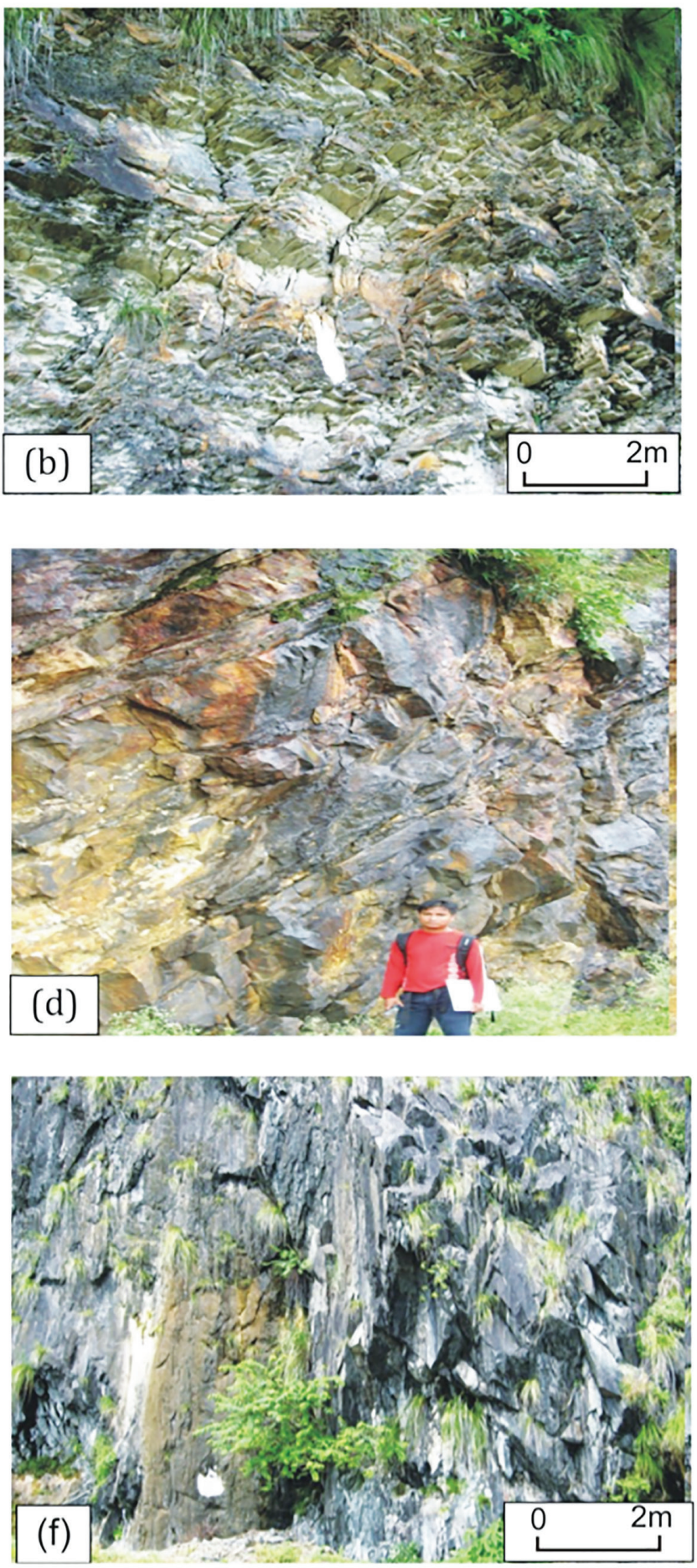

Fig. 4: (a) Grey Chandpur phyllite exposed near Lakhwar Dam site in upstream direction (b) Highly folded and crushed Chandpur phyllite exposed about $2 \mathrm{~km}$ from Judo towards Yamuna Bridge (c) Highly dipping thick beds of Nagthat quartzite exposed near Yamuna Bridge (d) Fine-grained Nagthat quartzite having thick coating of limonite along bedding and joints, $2 \mathrm{~km}$ from Yamuna Bridge along Yamuna Bridge - Chakrata Road (e) Criss-cross joints in Nagthat quartzite exposed $3 \mathrm{~km}$ from Yamuna Bridge towards Judo (f) Exposure of massive dolerite sill near Lakhwar Dam axis. 
trending fault coinciding with the axis of the anticline that is developed in Mussoorie syncline.

Orientation of beds is continuously varying at different places. To the north of Aglar, the quartzite beds have dip amount of $50^{\circ}-55^{\circ}$ towards N10 ${ }^{\circ}$ E. Similar trend of beds attitude is seen near Aglar Bridge, but have dip amount is low i.e. $37^{\circ}-40^{\circ}$. The attitude of beds near Judo village vary as strike $\mathrm{N} 75^{\circ} \mathrm{W}-\mathrm{S} 75^{\circ} \mathrm{E}$ and dip of $54^{\circ}-60^{\circ}$ towards $\mathrm{S} 15^{\circ} \mathrm{W}$; strike $\mathrm{N} 60^{\circ} \mathrm{W}-\mathrm{S} 60^{\circ} \mathrm{E}$ and dip of $53^{\circ}$ towards $\mathrm{N} 30^{\circ} \mathrm{E}$; strike $\mathrm{N} 70^{\circ} \mathrm{E}-\mathrm{S} 70^{\circ} \mathrm{W}$ and dip of $48^{\circ}$ towards $\mathrm{S} 20^{\circ} \mathrm{E}$. Occasionally thin slate bands are also present within the quartzites. This formation is exposed in the upstream vicinity of dam, on the left bank and extends northward over the right bank forming a broad open fold. In the left bank, the quartzite comes in juxtaposition of slate xenolith with a faulted contact. Grey and olive greenish slates of Blaini Formation resting on Nagthat Formation is exposed along the Yamuna Bridge-Kempty road generally have an attitude of NW-SE strike with dip amount of $30^{\circ}-35^{\circ}$.

\section{METHODOLOGY}

Stability analysis is based on the principle of comparing shear stress occurring along probable discontinuities with the shear strength of the slope materials resisting the stress. The strength of slope materials yielded by their geotechnical, mineralogical and chemical properties and stresses acting on them are major factors in slope instability (Abramson, 1996).

Drainage characteristics, fracturing and degree of weathering are also equally important factors triggering slope failure. Hence, thorough fieldwork related to morphology, structural and lithological characteristics of slide zones along with analysis of material properties for understanding the slide mechanisms are essential.
In the study area, the based on the debris volume, and subsequent impact on road, 10 major hazardous slide zones were identified. They are named as per their locations with suffix slide regardless of mass movement type. The failure type was decided by interrelationship of discontinuity and slope orientations plotted in the stereonet. Accordingly, four slides were categorized as translational slides representing planar and wedge failure types and dealt for detailed study. They are Lakhwar Dam Axis Slide (LDAS), Aglar North Slide (ANS), Aglar Bridge Slide (ABS) and Raira Slide (RS) (Fig. 5 and Table 1).

Geometrical dimensions of slides viz. the total length from tip to its crown, where tip is the point on the toe farthest from the top and width of the slide was measured at road. Latitude-longitudes and elevation of slide zones were determined by GPS and marked in 1:50000 scale Survey of India toposheet. Lithology, structural features, and orientation of possible discontinuities as faults, joints and beds were measured in the field.

The plan view of each slide zone was divided into sections vertically from crown to toe, representative 2-3 soil and rock samples were collected from each divided sections i.e. 6 samples and each of $5 \mathrm{~kg}$ are collected from one slide. The uniaxial compressive strength for rock samples were analyzed as per the standard methods (BIS 1986) in geotechnical lab of DBS College, Dehradun.

It is well know that the slope is stable when equilibrium of resisting and inducing forces is maintained. Factor of safety is the ratio of these forces and can be used as index to quantify the slope stability. This ratio more than unity reveals stability. Every slide zones have many sections having variable FS. However, FS in this study was calculated for individual divided sections of slides but precisely do not define its distribution throughout the slide.

Table 1: Hazardous Translational Slide Zones studied in route from Judo to Kandi village, National Highway 507.

\begin{tabular}{|c|c|c|c|c|c|c|c|c|c|}
\hline $\begin{array}{l}\text { Name of } \\
\text { the slide }\end{array}$ & Coordinates & Location & $\begin{array}{c}\text { Failure } \\
\text { type }\end{array}$ & $\begin{array}{l}\text { Lan } \\
\text { Dim }\end{array}$ & $\begin{array}{l}\text { lide } \\
\text { asion }\end{array}$ & $\begin{array}{c}\text { Slope } \\
\text { attitude }\end{array}$ & $\begin{array}{c}\text { Joint } \\
\text { Pattern }\end{array}$ & $\begin{array}{l}\text { Vegetation } \\
\text { Cover }\end{array}$ & Status \\
\hline $\begin{array}{l}\text { Lakhwar } \\
\text { Dam axis } \\
\text { slide }\end{array}$ & $\begin{array}{l}77^{\circ} 56^{\prime} 58^{\prime \prime} \\
30^{\circ} 31^{\prime} 16^{\prime \prime}\end{array}$ & $\begin{array}{l}5.5 \mathrm{~km} \text { from Yamuna } \\
\text { bridge on right bank } \\
\text { of Yamuna river near } \\
\text { Lakhwar dam axis }\end{array}$ & Planar & 220 & 95 & $\begin{array}{c}>60^{\circ} / \\
\text { S400W }\end{array}$ & $\begin{array}{l}830 \mathrm{SE}, \\
670 \mathrm{NE}\end{array}$ & $\begin{array}{l}\text { Sparsely } \\
\text { vegetated }\end{array}$ & Active \\
\hline $\begin{array}{l}\text { Aglar } \\
\text { North } \\
\text { Slide }\end{array}$ & $\begin{array}{l}77^{\circ} 59^{\prime} 25^{\prime \prime} \\
30^{\circ} 31^{\prime} 20^{\prime \prime}\end{array}$ & $\begin{array}{l}1 \mathrm{~km} \text { in northwest } \\
\text { from Aglar bridge } \\
\text { towards Nainbag }\end{array}$ & Wedge & 340 & 125 & $\begin{array}{c}>45^{\circ} / \\
\text { S400W }\end{array}$ & $\begin{array}{c}200 \mathrm{NW} \text {, } \\
160 \mathrm{SW} \\
\text { and S. }\end{array}$ & $\begin{array}{l}\text { Sparsely } \\
\text { vegetated }\end{array}$ & $\begin{array}{l}\text { Nearly } \\
\text { stable }\end{array}$ \\
\hline $\begin{array}{l}\text { Aglar } \\
\text { bridge } \\
\text { slide }\end{array}$ & $\begin{array}{l}78^{\circ} 00^{\prime} 05^{\prime \prime} \\
30^{\circ} 30^{\prime} 45^{\prime \prime}\end{array}$ & $\begin{array}{l}\text { Near Aglar bridge on } \\
\text { the left bank of Aglar } \\
\text { river. }\end{array}$ & Wedge & 90 & 130 & $\begin{array}{c}>60^{\circ} / \\
\text { S500W }\end{array}$ & $\begin{array}{l}\text { N100W, } \\
\text { S200W, } \\
\text { N2300 }\end{array}$ & $\begin{array}{l}\text { No cover, } \\
\text { small } \\
\text { bushes }\end{array}$ & Active \\
\hline $\begin{array}{l}\text { Raira } \\
\text { slide }\end{array}$ & $\begin{array}{l}77^{\circ} 55^{\prime} 15^{\prime \prime} \\
30^{\circ} 30^{\prime} 50^{\prime \prime}\end{array}$ & $\begin{array}{l}1 \mathrm{~km} \text { from Judo } \\
\text { toward Lakhwar dam } \\
\text { colony on the left } \\
\text { bank of Yamuna river. }\end{array}$ & Wedge & 95 & 30 & $\begin{array}{c}>50^{\circ} / \\
\mathrm{N} 50 \mathrm{~W}\end{array}$ & $\begin{array}{l}\text { N300E, } \\
\text { N350W, } \\
\text { S380E }\end{array}$ & $\begin{array}{l}\text { Almost } \\
\text { absent }\end{array}$ & Stabilized \\
\hline
\end{tabular}


For estimating factor of safety, limit equilibrium approach was applied (Hoek et al., 1981) for which cohesion and angle of internal friction are necessary parameters. Cohesion and the angle of internal friction are fundamental geotechnical parameters that define the mechanical characteristics of slope materials in view of its stability (Zydroń et al., 2011). Internal friction in the rock mass is owing to the interlocking of its particles and the forces tending to hold the particles together defines its cohesion (Bareither, 2008). Planar and wedge failures were determined by using Rock mass classification systems viz. Rock Mass Rating and modified Slope Mass Rating.

Intrinsic properties of rock mass are sought upon in these classification systems, for knowing the behavior of the rock mass (Milne et al., 1998). Rock mass rating (RMR), developed by Bieniawski (1979), utilizes these properties observed in field and estimated in lab to empirically know the quality and thereby stability of rock mass. Ratings have been given to each properties as number, spacing and surface properties of the structural discontinuities, the strength of the intact rock mass, the influence of subsurface groundwater, and the orientation of prevailing discontinuities (Tables 2 and 3).

For the inclusion of orientation data in rating system, Romana (1985) proposed Slope Mass Rating (SMR) and modified RMR by treating it with adjustment factors considering joint orientations present in the field and method of excavation (Table 4, Table 5). Orientations of slope and discontinuities plotted in stereographic projections were used to assign rating for adjustment factors in SMR. Also kinematic analysis was done to determine the possible mode of failures as well as geometry of the wedge failure for estimating its factor of safety. After identifying, the possible mode of failure (planar or wedge), other input parameters required for calculating the factor of safety were also determined by stereographic plots.

\section{RESULTS AND DISCUSSION}

Slope stability assessment of the hazardous slide zones in the route was done by integrating field observations regarding structural discontinuities and slope, with the lab analysis of geotechnical parameters of rock

Table 2: Rock Mass Rating Scheme after Bieniawski (1979).

\begin{tabular}{|c|c|c|c|c|c|c|c|}
\hline \multirow{3}{*}{$\begin{array}{l}\text { S.No. } \\
1 .\end{array}$} & \multicolumn{2}{|c|}{ Parameter } & \multicolumn{5}{|c|}{ Range of values } \\
\hline & $\begin{array}{l}\text { Strength of } \\
\text { intact rock } \\
\text { material }\end{array}$ & $\begin{array}{l}\text { Point load } \\
\text { Strength Index } \\
(\mathrm{MPa})\end{array}$ & $>10 \mathrm{MPa}$ & 4-10 MPa & $2-4 \mathrm{MPa}$ & $1-2 \mathrm{MPa}$ & $\begin{array}{c}\text { For this } \\
\text { low range } \\
\text { uniaxial } \\
\text { compressive } \\
\text { test is } \\
\text { preferred }\end{array}$ \\
\hline & & $\begin{array}{l}\text { Uniaxial } \\
\text { Compressive } \\
\text { Strength (MPa) } \\
\text { Rating }\end{array}$ & $>250 \mathrm{MPa}$ & $100-250 \mathrm{MPa}$ & 50-100 MPa & $25-50 \mathrm{MPa}$ & $\begin{array}{c}\text { 5-25 } \mathrm{MPa} \\
1-5 \mathrm{MPa} \\
<1 \mathrm{MPa} \\
2,1,0\end{array}$ \\
\hline \multirow[t]{2}{*}{2.} & \multirow{2}{*}{\multicolumn{2}{|c|}{$\begin{array}{l}\text { Drill Core } \\
\text { Quality (RQD \%) } \\
\text { Rating }\end{array}$}} & $90-100$ & $75-90$ & $50-75$ & $25-50$ & $<25$ \\
\hline & & & 20 & 17 & 13 & 8 & 3 \\
\hline 3. & \multicolumn{2}{|c|}{$\begin{array}{l}\text { Spacing of Discontinuity } \\
\text { Rating }\end{array}$} & $\begin{array}{c}>2 \mathrm{~m} \\
20\end{array}$ & $\begin{array}{l}0.6-2 \mathrm{~m} \\
15\end{array}$ & $\begin{array}{c}200-600 \mathrm{~mm} \\
10\end{array}$ & $\begin{array}{c}60-200 \mathrm{~mm} \\
8\end{array}$ & $\begin{array}{l}<60 \mathrm{~mm} \\
5\end{array}$ \\
\hline \multirow[t]{2}{*}{4.} & \multicolumn{2}{|c|}{$\begin{array}{l}\text { Conditions of } \\
\text { Discontinuity }\end{array}$} & $\begin{array}{l}\text { Very rough } \\
\text { surfaces. Not } \\
\text { continuous. } \\
\text { No separation. } \\
\text { Unweathered } \\
\text { wall rock. }\end{array}$ & $\begin{array}{l}\text { Slightly rough } \\
\text { surfaces. } \\
\text { Separation } \\
<1 \mathrm{~mm} \text {. Slightly } \\
\text { weathered walls }\end{array}$ & $\begin{array}{l}\text { Slightly rough } \\
\text { surfaces. } \\
\text { Separation < } \\
\text { 1mm. Highly } \\
\text { weathered } \\
\text { walls. }\end{array}$ & $\begin{array}{l}\text { Slickensided } \\
\text { surfaces or } \\
\text { gouge }<5 \\
\text { mm thick or } \\
\text { separation } 01-5 \\
\text { mm continuous. }\end{array}$ & $\begin{array}{c}\text { Soft Gouge } \\
>5 \mathrm{~mm} \text { thick } \\
\text { or Separation } \\
>5 \mathrm{~mm} \\
\text { Continuous }\end{array}$ \\
\hline & \multicolumn{2}{|c|}{ Rating } & 30 & 25 & 20 & 10 & 0 \\
\hline 5. & \multicolumn{2}{|c|}{$\begin{array}{l}\text { Groundwater condition } \\
\text { Rating }\end{array}$} & $\begin{array}{c}\text { Complete Dry } \\
15\end{array}$ & $\begin{array}{c}\text { Damp } \\
10\end{array}$ & $\begin{array}{c}\text { Wet } \\
7\end{array}$ & $\begin{array}{l}\text { Dripping } \\
4\end{array}$ & $\begin{array}{c}\text { Flowing } \\
0\end{array}$ \\
\hline
\end{tabular}

Table 3: Classification of Rock Mass based on Rock Mass Rating (Bieniawski, 1979).

\begin{tabular}{llccccc}
\hline \multirow{2}{*}{\begin{tabular}{c} 
S.No. \\
\cline { 3 - 6 }
\end{tabular}} & Parameters/Properties of rock & \multicolumn{5}{c}{ Rock Mass Rating (Rock Class) } \\
\cline { 3 - 6 } & & $100-81(\mathrm{I})$ & $80-61(\mathrm{II})$ & $60-41(\mathrm{III})$ & $40-21(\mathrm{IV})$ & $<20(\mathrm{~V})$ \\
\hline 1 & Classification of rock mass & Very Good & Good & Fair & Poor & Very Poor \\
2 & Cohesion of rock mass (MPa) & $>0.4$ & $0.3-0.4$ & $0.2-0.3$ & $0.1-0.2$ & $<0.1$ \\
3 & Angle of Internal Friction & $>45^{\circ}$ & $35^{\circ}-45^{\circ}$ & $25^{\circ}-35^{\circ}$ & $15^{\circ}-25^{\circ}$ & $15^{\circ}$ \\
\hline
\end{tabular}


Table 4: Adjustment ratings for joints using modified SMR approach (after Romana, 1985).

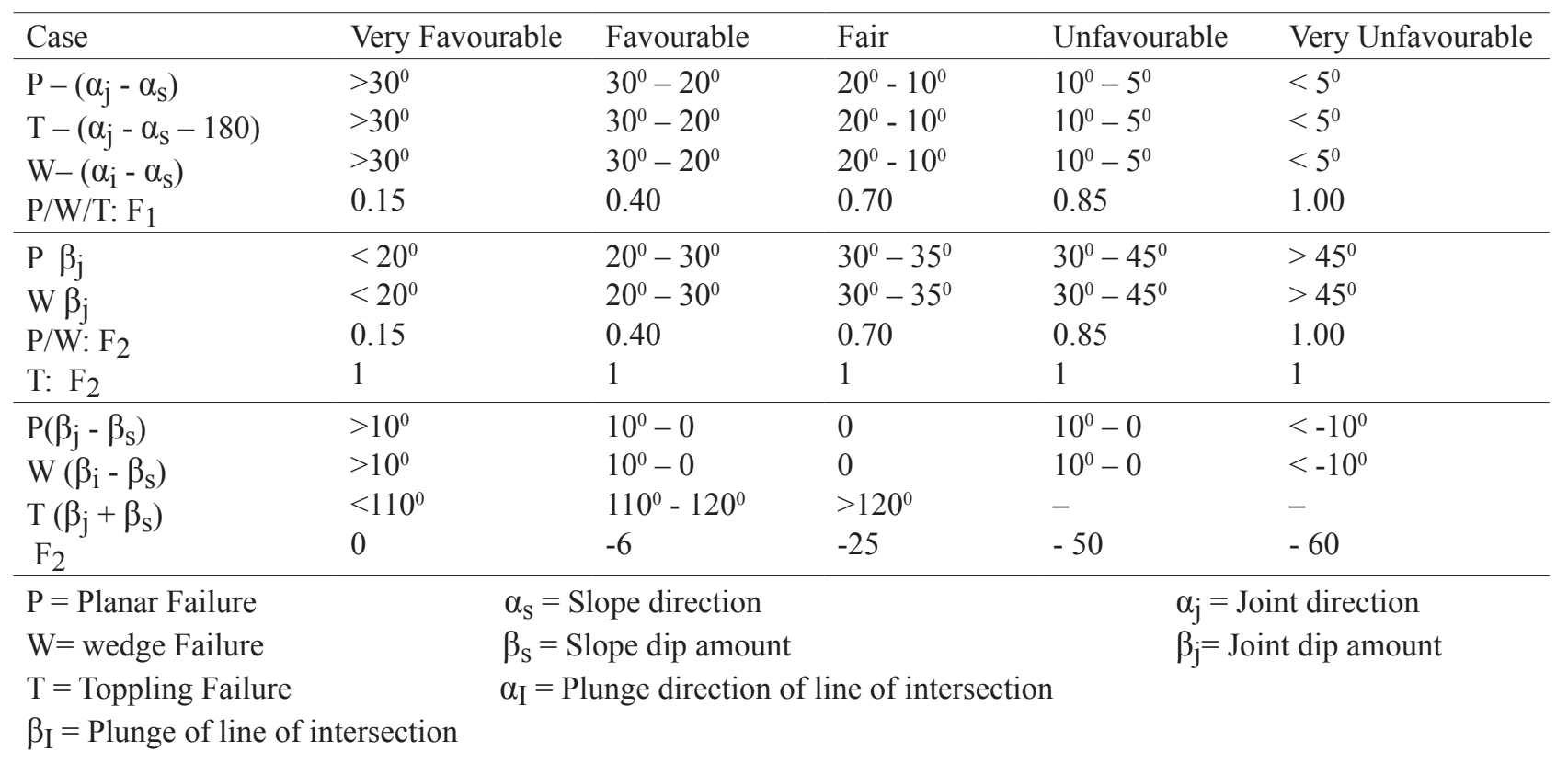

Table 5: Stability classes as per SMR values (Romana, 1985).

\begin{tabular}{|c|c|c|c|c|c|}
\hline Class & $\mathrm{V}$ & IV & III & II & I \\
\hline SMR Value & $0-20$ & $21-40$ & $41-60$ & $61-80$ & $81-100$ \\
\hline $\begin{array}{l}\text { Rock Mass } \\
\text { Description }\end{array}$ & Very bad & Bad & Normal & Good & Very Good \\
\hline Stability & $\begin{array}{l}\text { Completely } \\
\text { unstable }\end{array}$ & Unstable & Partially stable & Stable & Completely stable \\
\hline Failures & $\begin{array}{l}\text { Big Planar or } \\
\text { circular }\end{array}$ & $\begin{array}{l}\text { Planar or big } \\
\text { wedges }\end{array}$ & $\begin{array}{l}\text { Planar along } \\
\text { some joint and } \\
\text { many wedges }\end{array}$ & $\begin{array}{l}\text { Some block } \\
\text { failure }\end{array}$ & No failure \\
\hline $\begin{array}{l}\text { Probability of } \\
\text { failure }\end{array}$ & 0.9 & 0.6 & 0.4 & 0.2 & 0 \\
\hline
\end{tabular}

mass. After that the data are assessed and interpreted to assess the stability of slope. Level of instability cannot be exactly foreseen but indications can be sought before failure by monitoring its rock mass properties and other exogenic and endogenic factors. Interplay of a number of factors: discontinuity and strength characteristics of the rock mass, degree of weathering, the slope topography and the interaction of the water with the slope are responsible for the instability of slope. Presence of Aglar fault and other small faults adversely affected the strength of slope materials in and around slide zones, as seen in their geometric and physio-mechanical properties. As the water percolates, it increased stresses by pore water pressure or the loss of strength by saturation, seepage pressure, steepening of slope and weathering. Water percolation rate is function of soil properties and influenced by the rainfall as well.

The stability analysis determines the safety factors accounting variety of causes that represents the state of strength and possibilities of the slopes to fail, typically given by an index called Factor of Safety (FS) (Hoek and Bray, 1981). The quantitative determination of the stability of slopes, in general, must be based on knowledge regarding the geological structure of the area, the detailed composition and orientation of the strata, and the geomorphological history of the land surface. For estimating the factor of safety, type of failure should be known, that can be determined by using kinematic analysis.

\section{Kinematic Analysis}

Kinematic analysis is done to understand the role of the discontinuities in slope failures, whether the orientation of discontinuities could cause instability of considered slope or not. If discontinuities are unfavorably aligned, it can also predict the possible directional attributes of future slope movement.

It is based on Markland's test (Markland, 1972, Hoek and Bray, 1981). It utilizes a stereographic projection of the great circle representing the slope face together with a circle representing the friction angle $(\phi)$, of the discontinuity. Their interrelationships are then sought to determine the most unfavorably aligned discontinuity with respect to slope and accordingly type of failure whether planar or wedge. Worth mention that either type of failure occurs when specific geometric combinations. Planar type of 
failure occurs when strike of discontinuity ( $\alpha \mathrm{j})$ is almost parallel or within 20 to the slope strike ( $\alpha$ s). The dip of discontinuity must be less than the slope angle and should be greater than the friction angle i.e. $\beta \mathrm{s}>\beta \mathrm{j}>\phi$. Lastly, the upper part of the sliding surface must either intersect the upper slope or terminate in a tension crack. In the present study, Lakhwar Dam axis slide is found to be showing planar failure.

In kinematic analysis, orientation of the line of intersection of discontinuities and the direction of sliding forming the wedge failure can be determined. It occurs when the plunge ( $\beta i$ ) i.e. the angle of two intersections must be less than the slope angle $(\beta s)$ but higher than the friction angle $(\phi)$ of the two slide planes, or $\beta s>\beta i>\phi$ and the plunge direction should be out of the slope face for sliding to occur. Aglar North Slide, Aglar Bridge Slide and Raira Slide are wedge failure slides.

\section{Rock Mass Classification}

Rock mass classification system is an empirical method used for preliminary estimation of slope stability and probability of failure (Singh \& Goel, 1999; Gupta et al., 2013; Vishal et al., 2015; Singh et al., 2017). They can also be employed to estimate components of strength in planar and wedge failures. Rock Mass Rating (RMR) and Slope Mass Rating (SMR) are prevalent classifications indicating rock mass grades and slope vulnerability. It is based on the quantitative estimation of parameters that are affecting rock mass (Sarkar et al., 2012b; Siddique, 2018). These parameters are rock quality designation (RQD), uniaxial compressive strength (UCS), spacing and filling condition of discontinuities and groundwater conditions

Rock samples were drilled to form cylindrical cores. Uniaxial Compressive Strength (UCS) was then assessed by applying compressive load on parallel ends to these cores and calculated as load at failure divided by the area of cross section of the core. Intact rocks of LDA and ANS slides have high strength lying in class B of Deere classification (Deere, 1964) with UCS 112-224 MPa while ABS and RS slides lie in class C having medium strength with UCS 56-112 $\mathrm{MPa}$.

Rock quality designation (RQD) is percent core recovery which incorporates only sound pieces of core that are $100 \mathrm{~mm}$ or greater in length along core axis. It is calculated using equation 1 .

$\mathrm{RQD}=\frac{\text { sum of core pieces } \geq 10 \mathrm{~cm} \times 100}{\text { total drill run }}$ . .1

The process is rather expensive, and cores were not available. Therefore, indirect method i.e. volumetric joint count method was applied. They were obtained by field survey using graph of mean discontinuity spacing and density. RQD was then calculated by expression (Palmstrom, 1982) given as RQD $=115$ $3.3 \mathrm{Jv}$ involving number of joints per unit volume $\left(\mathrm{Jv}_{\mathrm{v}}\right)$ of rock mass. After determining the RQD, rating was given according to Table 2 .

Another parameter considered in RMR is spacing and condition of discontinuities. Spacing is perpendicular distance between discontinuities and condition involves roughness, infilling and weathering of rock. Most critical joint sets are considered for spacing as well as for infilling.

Water plays a significant role in destabilizing a slope. Be its continuous seepage causing weathering and formation of clay minerals within joints that can easily failure by lubrication, also increase in pore pressure promote instability of slope. Groundwater conditions are reported as completely dry, damp, wet, dripping, and flowing (BIS, 1998a). If the rock mass is fully saturated, water may freely flow or dripping while in unsaturated condition, the area may be wet, damp, or dry. In the area, RMR for both wet and dry conditions were estimated. Evaluation of RMR by rating each parameter was done for the slides (Table 6).

As per estimated RMR, in dry conditions, rocks mass in and around all slide zones are falling in class II indicating rocks to be of good quality but during saturated conditions, class III is observed classifying rock as of fair category.

Even the good rock mass can be prone to sliding, if orientation of discontinuities with respect to slope is unfavorable. Thus, for incorporating this aspect, RMR was treated with adjustment factors to estimate slope mass rating (SMR). Adjustment factors $\left(\mathrm{F}_{1}, \mathrm{~F}_{2}, \mathrm{~F}_{3}\right.$ and $\mathrm{F}_{4}$ ) are ratings given to orientations of discontinuities and slope, when these are plotted in stereonet.

$F_{1}$ reflects parallelism between slope and discontinuity strike. It varies between 1.00 when both are parallel to 0.15 where the angle between the slope strike and the strike of discontinuity surface is more than $30^{\circ}$. $\mathrm{F}_{2}$ refers to the dip of discontinuity plane. It ranges between 1.00 (for $\operatorname{dips}>45^{\circ}$ ) to 0.65 (for $\operatorname{dips}<20^{\circ}$ ). $\mathrm{F}_{3}$ refers to angular difference between discontinuity dip angle and slope angle. It ranges from 0 (for angular difference $>10^{\circ}$ ) to 60 (for angular difference $<-10^{\circ}$ ). $\mathrm{F}_{4}$ is for method of excavation ranging from 15 to -8 . Nevertheless, all the slide zones are along roads and all slopes are cut or excavated through mechanical means for the construction of roads hence, $F_{4}$ is taken as 0 . SMR classification is given in Table 7 with obtained adjustment factors.

Rock mass that was indicated good or fair by RMR, it became normal or bad when the discontinuity orientations with respect to slope face are taken into 
Table 6: Rock Mass Rating of slide zones.

\begin{tabular}{|c|c|c|c|c|c|c|c|c|c|c|c|}
\hline $\begin{array}{l}\text { Name of } \\
\text { the slide }\end{array}$ & Rock type & $\begin{array}{l}\text { UCS } \\
(\mathrm{MPa})\end{array}$ & $\begin{array}{l}\text { RQD } \\
(\%)\end{array}$ & $\begin{array}{c}\text { Spacing } \\
\text { of } \\
\text { Joints }\end{array}$ & $\begin{array}{l}\text { Condition of } \\
\text { Joints }\end{array}$ & $\begin{array}{c}\text { Ground } \\
\text { water } \\
\text { condition }\end{array}$ & $\begin{array}{l}\text { RMR } \\
\text { value }\end{array}$ & $\begin{array}{l}\text { RMR } \\
\text { Class }\end{array}$ & Description & $\begin{array}{c}\text { Cohesion } \\
\text { of Rock } \\
\text { Mass (c) } \\
(\mathrm{MPa})\end{array}$ & $\begin{array}{l}\text { Angle of } \\
\text { Internal } \\
\text { friction } \\
(0)\end{array}$ \\
\hline \multirow[t]{2}{*}{$\begin{array}{l}\text { Lakhwar } \\
\text { Dam Axis } \\
\text { Slide }\end{array}$} & \multirow[t]{2}{*}{ Dolorite } & 114 & 52 & 0.14 & $\begin{array}{l}\text { Slightly rough } \\
\text { and moderate to } \\
\text { high weathered } \\
\text { slickenside wall } \\
\text { rock surface }\end{array}$ & $\begin{array}{c}\text { Dry } \\
15\end{array}$ & 63 & II & Good rock & 0.146 & 19 \\
\hline & & 12 & 13 & 8 & 15 & $\begin{array}{l}\text { Wet } \\
7\end{array}$ & 55 & III & Normal rock & 0.104 & 14.96 \\
\hline \multirow[t]{2}{*}{$\begin{array}{l}\text { Aglar North } \\
\text { Slide }\end{array}$} & \multirow[t]{2}{*}{ Quartzite } & 138 & 53 & 0.14 & $\begin{array}{l}\text { Slightly rough } \\
\text { and moderate } \\
\text { to highly } \\
\text { weathered wall } \\
\text { rock surface. } \\
\text { Separation < } \\
1 \mathrm{~mm}\end{array}$ & $\begin{array}{c}\text { Dry } \\
15\end{array}$ & 68 & II & Good rock & 0.221 & 24.79 \\
\hline & & 12 & 13 & 8 & 20 & $\begin{array}{c}\text { Wet } \\
7\end{array}$ & 60 & III & Normal rock & 0.125 & 16.91 \\
\hline \multirow[t]{2}{*}{$\begin{array}{l}\text { Aglar } \\
\text { Bridge } \\
\text { Slide }\end{array}$} & \multirow[t]{2}{*}{ Quartzite } & 75 & 53 & 0.14 & $\begin{array}{l}\text { Slightly rough } \\
\text { and moderate } \\
\text { to highly } \\
\text { weathered wall } \\
\text { rock surface. } \\
\text { Separation < } \\
1 \mathrm{~mm}\end{array}$ & $\begin{array}{c}\text { Dry } \\
15\end{array}$ & 63 & II & Good rock & 0.110 & 15.35 \\
\hline & & 7 & 13 & 8 & 20 & $\begin{array}{c}\text { Wet } \\
7\end{array}$ & 55 & III & Normal rock & 0.067 & 11.52 \\
\hline \multirow[t]{2}{*}{ Raira Slide } & \multirow[t]{2}{*}{ Quartzite } & 94 & 57 & 0.17 & $\begin{array}{l}\text { Slightly rough } \\
\text { and moderate } \\
\text { to highly } \\
\text { weathered wall } \\
\text { rock surface. } \\
\text { Separation < } \\
1 \mathrm{~mm}\end{array}$ & $\begin{array}{c}\text { Dry } \\
15\end{array}$ & 63 & II & Good rock & 0.300 & \\
\hline & & 7 & 13 & 8 & 20 & $\begin{array}{c}\text { wet } \\
7\end{array}$ & 55 & III & Normal rock & 0.254 & 29 \\
\hline
\end{tabular}

Table 7: Discontinuity and slope orientation data, their interrelationship and Slope Mass Rating values with adjustment factors.

\begin{tabular}{|c|c|c|c|c|c|c|c|c|c|c|c|c|c|c|}
\hline $\begin{array}{l}\text { Name of the } \\
\text { Slide }\end{array}$ & $\begin{array}{l}\text { Failure } \\
\text { type }\end{array}$ & $\left(\alpha_{\mathrm{j}} \text { or } \alpha_{\mathrm{i}}\right)^{0}$ & $\alpha \mathrm{s}^{0}$ & $\begin{array}{l}{\left[\left(\alpha_{\mathrm{j}} \text { or } \alpha_{\mathrm{i}}\right)-\right.} \\
\alpha \mathrm{s}]^{0}\end{array}$ & $\mathrm{~F}_{1}$ & $\begin{array}{l}(\beta \mathrm{j} \text { or } \\
\left.\beta_{\mathrm{i}}\right)^{0}\end{array}$ & $\mathrm{~F}_{2}$ & $\beta \mathrm{s}^{0}$ & $\begin{array}{l}{[(\beta \mathrm{j} \text { or }} \\
\left.\beta \mathrm{i})-\beta_{\mathrm{s}}\right]^{0}\end{array}$ & $\mathrm{~F}_{3}$ & $\mathrm{~F}_{4}$ & & RMR & SMR \\
\hline \multirow{2}{*}{$\begin{array}{l}\text { Lakhwar Dam } \\
\text { Axis Slide }\end{array}$} & \multirow[t]{2}{*}{ Planar } & \multirow[t]{2}{*}{$\mathrm{N} 225$} & \multirow[t]{2}{*}{ N 220} & \multirow[t]{2}{*}{5} & \multirow[t]{2}{*}{1} & \multirow[t]{2}{*}{50} & \multirow[t]{2}{*}{1} & \multirow[t]{2}{*}{60} & \multirow[t]{2}{*}{-10} & \multirow{2}{*}{-50} & \multirow[t]{2}{*}{15} & dry & 63 & 28 \\
\hline & & & & & & & & & & & & wet & 55 & 20 \\
\hline \multirow[t]{2}{*}{ Aglar North Slide } & \multirow[t]{2}{*}{ Wedge } & \multirow[t]{2}{*}{$\mathrm{N} 210$} & \multirow[t]{2}{*}{ N 220} & \multirow[t]{2}{*}{-10} & \multirow[t]{2}{*}{0.85} & \multirow[t]{2}{*}{48} & \multirow[t]{2}{*}{1} & \multirow[t]{2}{*}{60} & \multirow[t]{2}{*}{-2} & \multirow[t]{2}{*}{-60} & \multirow[t]{2}{*}{15} & dry & 68 & 32 \\
\hline & & & & & & & & & & & & wet & 60 & 24 \\
\hline \multirow{2}{*}{$\begin{array}{l}\text { Aglar Bridge } \\
\text { Slide }\end{array}$} & \multirow[t]{2}{*}{ Wedge } & \multirow[t]{2}{*}{ N 212} & \multirow[t]{2}{*}{ N 235} & \multirow[t]{2}{*}{-18} & \multirow[t]{2}{*}{0.7} & \multirow[t]{2}{*}{48} & \multirow[t]{2}{*}{1} & \multirow[t]{2}{*}{60} & \multirow[t]{2}{*}{-12} & \multirow[t]{2}{*}{-60} & \multirow[t]{2}{*}{0} & dry & 63 & 21 \\
\hline & & & & & & & & & & & & wet & 55 & 13 \\
\hline \multirow[t]{2}{*}{ Raira Slide } & Wedge & N 330 & N 5 & 325 & 0.15 & 33 & 0.7 & 55 & -22 & -60 & 0 & dry & 63 & 56.7 \\
\hline & & & & & & & & & & & & wet & 55 & 48.7 \\
\hline
\end{tabular}

Notations:

$\alpha_{s}$ - Slope direction; $\alpha_{j}$ - Joint direction; $\alpha_{i}$ Plunge direction of line of intersection of wedge forming joints;

$\beta_{s^{-}}$Slope amount; $\beta j$ - Joint dip; $ß i$ - Plunge of line of intersection of wedge forming joints

account. As Lakhwar Dam Slide and Aglar Bridge slide both have very bad rock mass and are completely unstable lying in class IV. Raira slide falls in III class that represents, normal rock mass and is partially unstable while Aglar North slide lies in class IV implying rock mass is bad with unstable conditions.

Estimated rock mass ratings are used for determining cohesion (c) and angle of internal friction $(\phi)$ as per guidelines provided by Bureau of Indian Standard guidelines [BIS 1998a]. Cohesion is varying from $0.067 \mathrm{MPa}$ to $0.3 \mathrm{MPa}$ while angle of internal friction is between $11.5^{\circ}$ and $33.1^{\circ}$. These strength parameters are foremost input in Factor of safety estimation of slide zones.

\section{Slope Stability Assessment of slide zones}

Analytical determination of stability by limit 
equilibrium approach combines strength parameters, slope and discontinuity characteristics (Kumar et al., 2017). Switching from stability to failure may be envisaged mathematically as a decrease in the factor of safety to values below unity. Factor of safety (FS) investigated in the study area varies from 1.1 to 5.9 in dry conditions while reduction in FS is observed with increasing saturation, seepage along the crack sand discontinuities during rainfall.
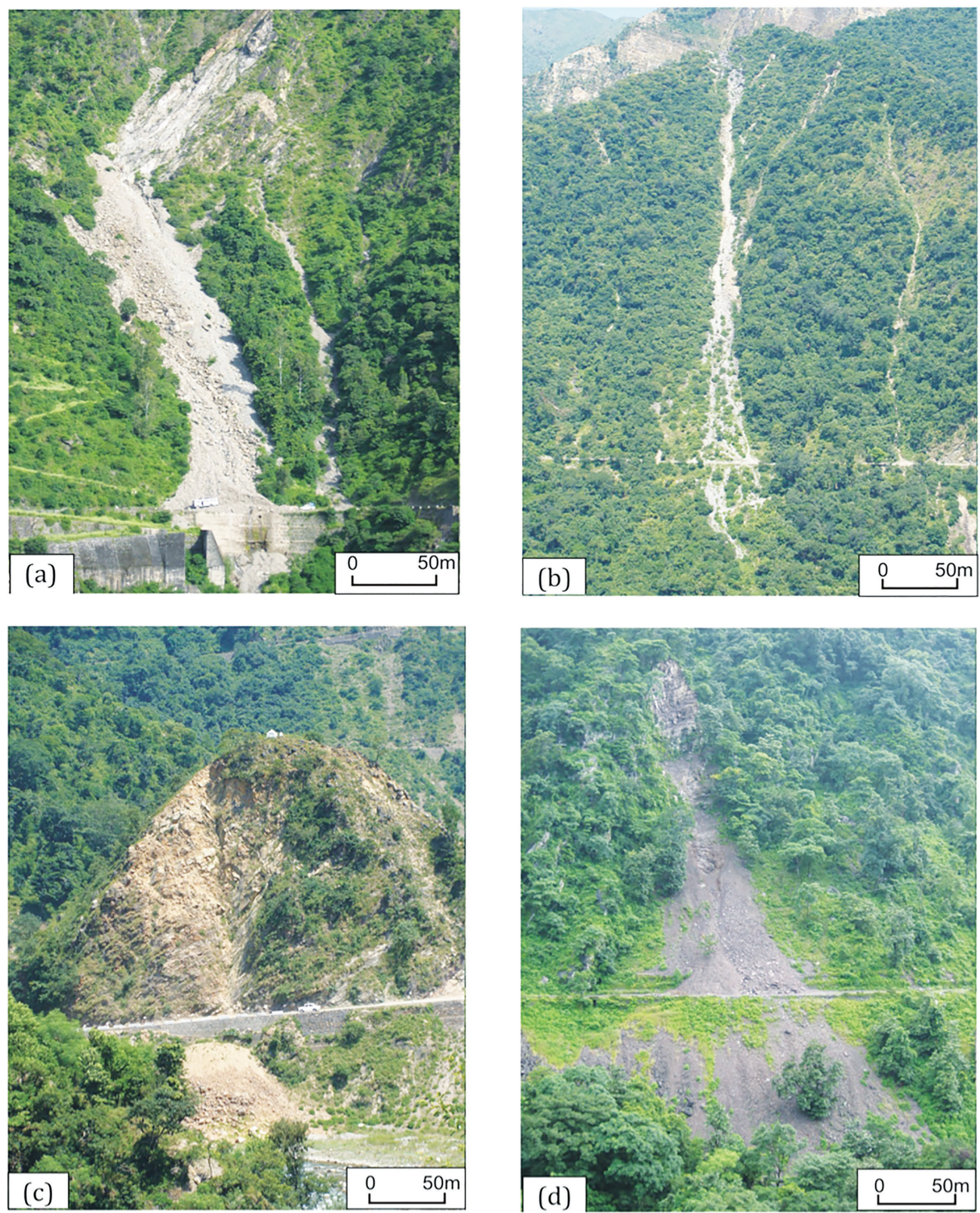

Fig. 5: (a) Lakhwar Dam Axis Slide showing planar failure at the upper section of the slide (b) Aglar North Slide with vegetation growing in the zone of accumulation i.e. above and below the road section (c) Aglar Bridge Slide having clearly visible wedge from hill top to road level (d) Raira slide with damaged retaining wall. 


\section{Lakhwar Dam Axis Slide}

This slide is situated $5.5 \mathrm{~km}$ away from the Yamuna Bridge near Lakhwar Dam Axis on National Highway 507 on the right bank of Yamuna River (Fig. 5a). Total length of slide is about $250 \mathrm{~m}$ having crown and toe at the elevation of $1020 \mathrm{~m}$ and $800 \mathrm{~m}$ respectively while a distance is about $95 \mathrm{~m}$ along the road. The main scarp of slide is $80 \mathrm{~m}$ long and 30-35 m wide (Fig. 6a). Being near to the dam axis, this slide can adversely affect the construction and operation of dam structure and powerhouse.

The slide is located on fairly steep slope of $60^{\circ}$ in
$\mathrm{S} 40^{\circ} \mathrm{W}$ adjoining the Yamuna River on its right bank where Nagthat quartzites are exposed dipping with $50^{\circ}$ towards $\mathrm{N} 85^{\circ} \mathrm{E}$ and strike $\mathrm{N} 5^{\circ} \mathrm{W}-\mathrm{S} 5^{\circ} \mathrm{E}$ and intruded with blackish, massive dolerite.

Two sets of joints observed in the slide zone are oriented with strike $\mathrm{N} 7^{\circ} \mathrm{E}-\mathrm{S} 7^{\circ} \mathrm{W}$; dip of $67^{\circ}$ due $\mathrm{S} 83^{\circ} \mathrm{E}$ and strike $\mathrm{N} 23^{\circ} \mathrm{W}-\mathrm{S} 23^{\circ} \mathrm{E}$; dip of $57^{\circ}$ due $\mathrm{N} 67^{\circ} \mathrm{E}$. Kinematic Analysis involving the three discontinuity sets $\mathrm{J}_{1}, \mathrm{~J}_{2}$ and bedding plane along with slope orientation (Fig.7). The results show that bedding plane associated with slope orientation is the responsible discontinuity and played an important role in triggering this slide (Fig.7).
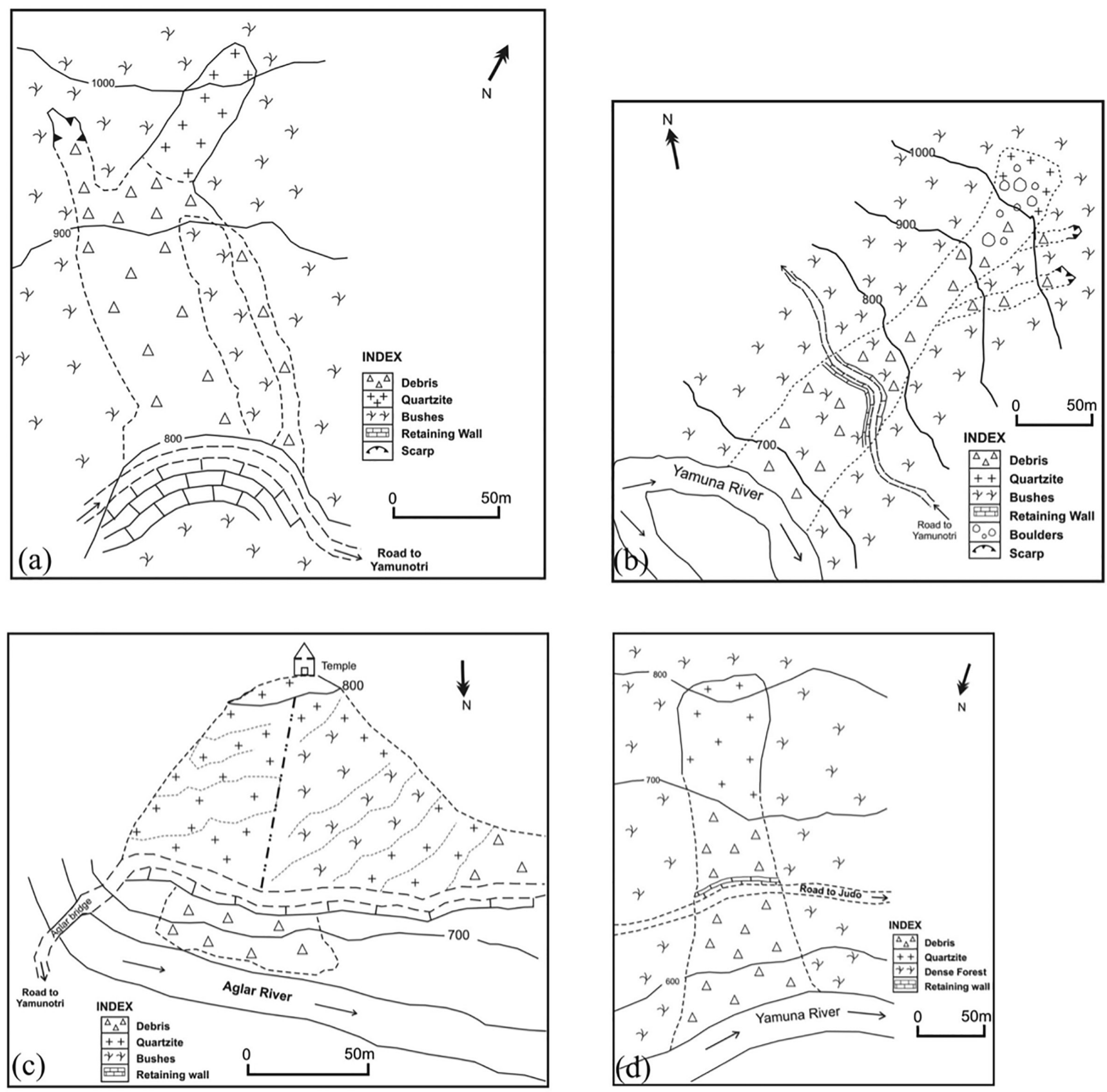

Fig. 6: Sketch map of (a) Lakhwar dam axis slide; (b) Aglar slide; (c) Aglar bridge slide; (d) Raira slide. 


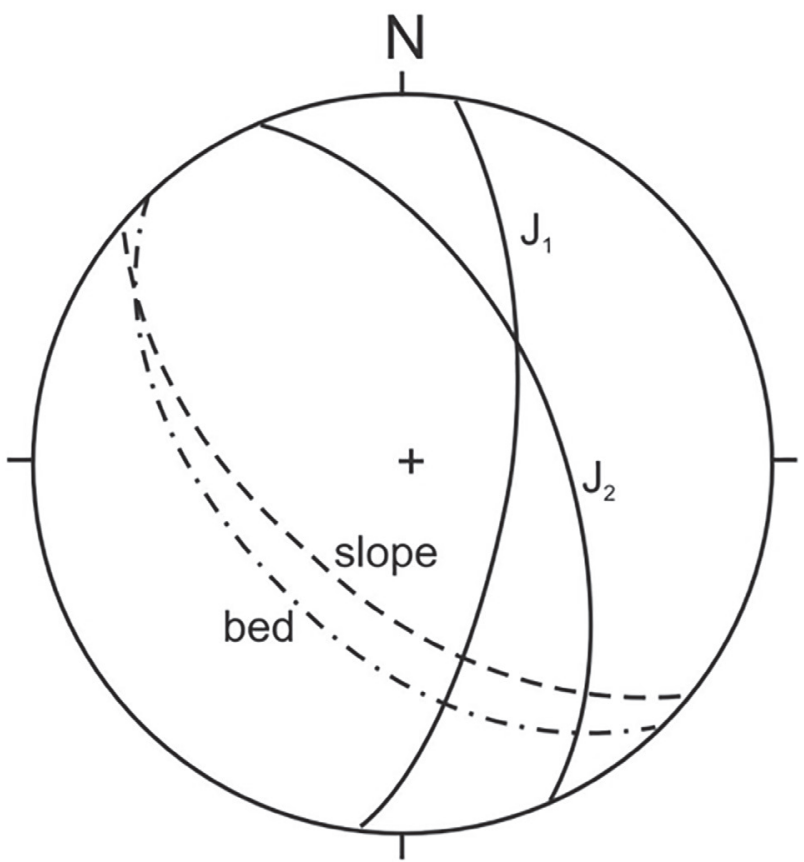

Fig. 7: Stereoplot of Lakhwar Dam Axis Slide showing planar type of failure.

The joints are slightly rough and moderate to highly weathered with average spacing of $0.14 \mathrm{~m}$. RQD is estimated to be $53 \%$ and average uniaxial compressive strength of rock samples is $114 \mathrm{MPa}$ giving Rock Mass Rating (RMR) 63 in dry groundwater conditions and 55 after rainfall. Accordingly the rock mass falls in class II and III of classification given by Bieniawski (1979), indicating them to be of good to fair type. But, as RMR is treated with adjustment factors (F1, F2, F3 and F4) to find Slope Mass Rating, the slope is found to be unstable with bad rock mass. Hence, based on the RMR and modified SMR approach, the cohesion and angle of internal friction are determined to be $0.146 \mathrm{MPa}$ and $19^{\circ}$ in dry and $0.104 \mathrm{MPa}$ and $14.96^{\circ}$ in wet groundwater conditions respectively.

Since the slope angle is more than dip of discontinuity (dip of bed in this case) which is greater than angle of internal friction $(\phi)$, the condition of planar failure is satisfied for this slide. The slide is then further analyzed for obtaining factor of safety in both wet as well as in dry conditions.

For analytical estimation of Factor of Safety of planar failure type slide, slope geometry is taken into account, considering the block to be in inclined plane (Fig.8).

Limit equilibrium method is based on the principle that ratio of resisting forces to driving forces at equilibrium is 1 and defines the ratio as factor of safety $(\mathrm{F})$. It is calculated using equation 2 .

$\mathrm{F}=\frac{\mathrm{c} \cdot \mathrm{A}+\left(\mathrm{W} \cdot \cos \Psi_{\mathrm{p}}-\mathrm{U}-\mathrm{V} \sin \Psi_{\mathrm{p}}\right) \tan \phi}{\mathrm{W} \cdot \sin \Psi_{\mathrm{p}}+\mathrm{V} \cdot \cos \Psi_{\mathrm{p}}}$

Where,

'c' represents cohesion $(\mathrm{MPa})$

' $A$ ' represents area of sliding plane $\left(\mathrm{m}^{2}\right)$

'W' represents weight of block $(\mathrm{kg})$

' $\Psi$ p'represents dip of failure plane $\left(^{\circ}\right)$

'U'represents uplift water pressure on discontinuity plane $(\mathrm{kg} / \mathrm{m})$

' $\mathrm{V}$ ' represents water pressure in tension crack $(\mathrm{kg} / \mathrm{m})$

' $\Phi$ ' represents angle of internal friction $\left(^{\circ}\right)$

In equation 2 , ' $\mathrm{A}$ ' is calculated using equation 3.

$\mathrm{A}=(\mathrm{H}-\mathrm{z}) \operatorname{cosec} \Psi \mathrm{p}$

Where,

' $\mathrm{H}$ ' represents height of slope face $(\mathrm{m})$. It is estimated by longitudinal profile of slide zones and approximately taken as the difference in elevation between highest and lowest point.

' $z$ ' represents depth of tension crack $(\mathrm{m})$

' $\Psi$ p' represents dip of failure plane $\left(^{\circ}\right)$

It is supposed that tension cracks are coinciding with the slope crest and striking parallel to the slope surface (Hoek et al., 1981). Depth of tension crack (z) can geometrically be calculated using equation 4 .

$\frac{\mathrm{z}}{\mathrm{H}}=1-\left(\cot \Psi_{\mathrm{f}} \cdot \tan \Psi_{\mathrm{p}}\right)$

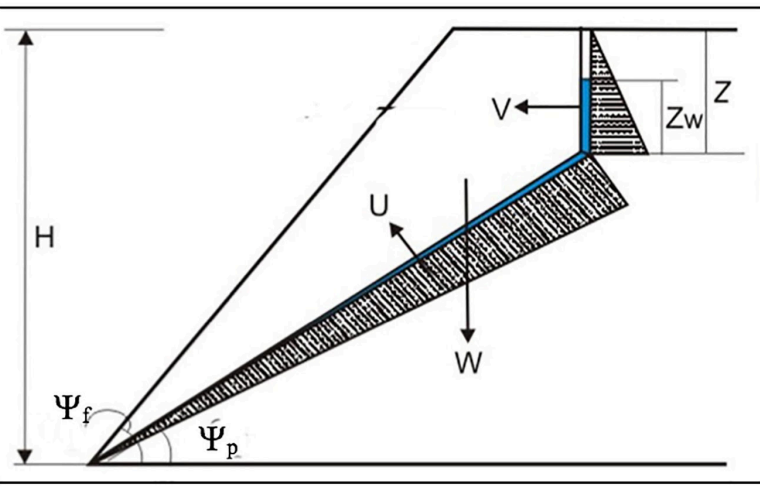

$\mathrm{H}=$ Height of slope face

$\mathrm{W}=$ Weight of block

$Z=$ Depth of tension crack

$Z_{\mathrm{w}}=$ depth of water in tension crack

$\Psi_{p}=$ dip of failure plane

$\Psi_{\mathrm{f}}=$ inclination of slope face

$\mathrm{V}=$ Water pressure in tension crack

$\mathrm{U}=$ Uplift water pressure on

discontinuity plane

Fig. 8: Diagram showing inclined plane considered for the factor of safety calculation. 
Where,

' $\mathrm{H}$ ' represents height of slope face $(\mathrm{m})$

$\Psi_{\mathrm{p}}=$ dip of failure plane $\left(^{\circ}\right)$

$\Psi_{\mathrm{f}}=$ inclination of slope face $\left(^{\circ}\right)$

In equation 2, ' $W$ ' is calculated using equation 5.

$\mathrm{W}=\frac{1}{2} \gamma \mathrm{H}^{2}\left(1-\frac{\mathrm{z}^{2}}{\mathrm{H}}\right) \cot \Psi_{\mathrm{p}}-\cot \Psi_{\mathrm{f}}$

Where,

' $\gamma$ ' represents density of rock $\left(\mathrm{gm} / \mathrm{cm}^{3}\right)$

' $\mathrm{H}$ ' represents height of slope face $(\mathrm{m})$

' $\mathrm{z}$ ' represents depth of tension crack $(\mathrm{m})$

' $\Psi$ p' represents dip of failure plane $\left({ }^{\circ}\right)$

' $\Psi \mathrm{f}$ ' represents inclination of slope face $\left(^{\circ}\right)$

In equation 2, ' $\mathrm{V}$ ' is calculated using equation 6.

$\mathrm{V}=\frac{1}{2} \gamma_{\mathrm{w}} \mathbf{z}_{\mathrm{w}}^{2}$

Where,

' $\gamma_{\mathrm{w}}$ ' represents density of water $\left(\mathrm{gm} / \mathrm{cm}^{3}\right)$

' $\mathrm{Zw}$ ' represents height of water in tension crack

(m) and $\mathrm{z}_{\mathrm{w}}=0.5 \mathrm{z}$.

In equation 2, ' $U$ ' is calculated using equation 7.

$\mathrm{U}=\frac{1}{2} \gamma_{\mathrm{w} \cdot \mathrm{Z}_{\mathrm{v}}}(\mathrm{H}-\mathrm{z}) \operatorname{cosec} \Psi \mathrm{p}$

Where,

' $\gamma_{\mathrm{w}}$ ' represents density of water $\left(\mathrm{gm} / \mathrm{cm}^{3}\right)$

' $\mathrm{Zw}$ ' represents height of water in tension crack (m)

' $\mathrm{H}$ ' represents height of slope face $(\mathrm{m})$

' $\mathrm{z}$ ' represents depth of tension crack $(\mathrm{m})$

' $\Psi_{\mathrm{p}}$ ' represents dip of failure plane $\left({ }^{\circ}\right)$

In dry condition, it is supposed the slope to be completely drained, though there may be moisture in the slope but will not influence its stability as long as no pressure is generated. Hence, under this condition with no water pressure in tension crack or along sliding surface, uplift pressure (U) and water pressure in tension crack (V) are both zero. Hence, Factor of safety for dry condition is calculated using equation 8 .

$\mathrm{F}=\frac{\mathrm{c} \cdot \mathrm{A}+\mathrm{W} \cdot \cos \Psi_{\mathrm{p}}}{\mathrm{W} \cdot \sin \Psi_{\mathrm{p}}} \tan \phi$

Where,

'c' represents cohesion $(\mathrm{MPa})$

'A' represents area of sliding plane $\left(\mathrm{m}^{2}\right)$

'W' represents weight of block $(\mathrm{kg})$
' $\Psi_{\mathrm{p}}$ ' represents dip of failure plane $\left(^{\circ}\right)$

' $\Psi_{\mathrm{f}}$ ' represents inclination of slope face $\left({ }^{\circ}\right)$

Thus, factor of safety determined (Table 8) for dry condition is 1.2 . For wet condition, $\mathrm{U}$ and $\mathrm{V}$ in equation 2 are taken into account. For wet condition, Uplift pressure on discontinuity plane (U) and water pressure in tension crack (V) is estimated to be 343200 $\mathrm{kg} / \mathrm{m}$ and $60500 \mathrm{~kg} / \mathrm{m}$ respectively and consequently factor of safety for wet condition is 0.75 .

The slope is seen to be critically stable with FS just equal to 1 in dry conditions but wet conditions, occurred either due to rainfall or other saturation source, caused its instability. As a remedial measure, the retaining walls are constructed, but channelization of surface water away from slide zone is necessary. Resisting external forces in the form of rock bolts or cable anchors can be applied as permanent remedial measures.

\section{Wedge Type Failure}

In wedge failure, intersection of two discontinuities forms failure when the plunge amount is less than slope angle and more than the angle of internal friction. Moreover, plunge direction of line of intersection of discontinuity planes and the direction of inclination of slope face have difference of $<20^{\circ}$. Aglar Bridge slide, Aglar North slide and Raira slide in the study route are satisfying conditions of wedge type of failure.

Stereonet projections of discontinuities and slope are used to determine the geometry of wedge and thereby input parameters. Cohesion and angle of internal friction are assumed as same for both discontinuity planes A and B. For dry conditions, $\gamma_{\mathrm{w}}$ is taken as zero while for wet conditions it is unit weight of water i.e. $1 \mathrm{t} / \mathrm{m} 3$. Factor of safety (F) (Hoek et al., 1981) is given by equation 9 .

$$
\mathrm{F}=\frac{3 \mathrm{c}_{\mathrm{A}}}{\gamma \mathrm{H}} * \mathrm{X}+\frac{3 \mathrm{c}_{\mathrm{B}}}{\gamma \mathrm{H}} * \mathrm{Y}+\left(\mathrm{A}-\frac{\gamma_{\mathrm{w}}}{2 \gamma} * \mathrm{X}\right) \tan \phi_{\mathrm{A}}+\left(\mathrm{B}-\frac{\gamma_{\mathrm{w}}}{2 \gamma} * \mathrm{Y}\right) \tan \phi_{\mathrm{B}}
$$

Where

' $\mathrm{C}_{\mathrm{A}}$ ', ' $\phi_{\mathrm{A}}{ }^{\prime}$ and $\mathrm{C}_{\mathrm{B}}$ ', ' $\phi_{\mathrm{B}}$ 'are the cohesive strengths (MPa) and the angles of friction $\left(^{\circ}\right)$ of plane $\mathrm{A}$ and $\mathrm{B}$ respectively

' $\gamma$ ' represents unit weight of rock $\left(\mathrm{gm} / \mathrm{cm}^{3}\right)$

' $\gamma_{\mathrm{w}}$ ' represents unit weight of water $\left(\mathrm{gm} / \mathrm{cm}^{3}\right)$

' $\mathrm{H}$ ' represents total height of wedge (m)

' $\mathrm{X}$ ', 'Y', 'A' and 'B' used in the equation 9 are dimensionless factors determined by stereo plot. These factors are dependent on the geometry of the wedge and given as: 


$$
\begin{aligned}
& \mathbf{A}=\frac{\cos \psi_{\mathrm{a}}-\cos \psi_{\mathrm{b}} \cdot \cos \theta_{\text {nanb }}}{\sin \psi_{5} \cdot \sin ^{2} \theta_{\text {nanb }}} ; \mathrm{B}=\frac{\cos \psi_{\mathrm{b}}-\cos \psi_{\mathrm{a}} \cdot \cos \theta_{\text {nanb }}}{\sin \psi_{5} \cdot \sin ^{2} \theta_{\text {nanb }}} \\
& \mathrm{X}=\frac{\sin \theta_{24}}{\sin \theta_{45} \cdot \cos \theta_{2 \mathrm{na}}} \quad ; \mathrm{Y}=\frac{\sin \theta_{13}}{\sin \theta_{35} \cdot \cos \theta_{1 \text {.na }}}
\end{aligned}
$$

Where $\Psi_{\mathrm{a}}$ and $\Psi_{\mathrm{b}}$ are the dips of the planes A and B respectively and $\Psi_{5}$ is the dip of the line of intersection along which the sliding of wedge taking place. Other subscripts of angle $\theta$ viz. nanb, 1na, 24,13 etc. are numbering of the lines of intersection of the various planes involved in failure represented in stereoplots (Fig. 9b,10b and 11b).

\section{Aglar North Slide}

This slide is situated at $1 \mathrm{~km}$ from the Aglar Bridge towards Nainbag on National Highway 507, in NW of the Aglar River (Fig. 5b). Located on fairly steep slope of $45^{\circ}$ in $220^{\circ} \mathrm{SW}$ direction, the zone of detachment of slide has maximum length and width of $70 \mathrm{~m}$ and $50 \mathrm{~m}$ respectively while, its zone of transportation is approximately $140 \mathrm{~m}$ in length and $30 \mathrm{~m}$ in width. Along the road, the slide is affecting a distance of about $90 \mathrm{~m}$ (Fig. 6b). The exposed rock in the area is brownish quartzites of the Nagthat Formation with strike $\mathrm{N} 80^{\circ} \mathrm{W}-\mathrm{S} 80^{\circ} \mathrm{E}$ and dip of $50^{\circ}-55^{\circ}$ towards $\mathrm{N} 10^{\circ} \mathrm{E}$.

Three sets of joints are observed having strike $\mathrm{N} 70^{\circ} \mathrm{E}$ $\mathrm{S} 70^{\circ} \mathrm{W}$ dip of $45^{\circ}$ due $\mathrm{N} 20^{\circ} \mathrm{W}$; strike $\mathrm{N} 74^{\circ} \mathrm{W}-\mathrm{S} 74^{\circ} \mathrm{E}$ dip of $50^{\circ}$ due $\mathrm{S} 16^{\circ} \mathrm{W}$; strike $\mathrm{N} 86^{\circ} \mathrm{E}-\mathrm{S} 86^{\circ} \mathrm{W}$ dip of $63^{\circ}$ due $\mathrm{S}$. All the joints and slope data is plotted in stereonet for deducing the resultant discontinuity pattern. It is observed that joints $\mathrm{J} 2$ and $\mathrm{J} 3$ along with the slope are responsible for the failure (Fig. 9a).

Joints are spaced with average spacing of $0.14 \mathrm{~m}$ and are slightly rough. Using joint orientation, spacing parameters from the field, RQD (53\%), and UCS (138 MPa) values, RMR is determined to be 68 for dry condition and 60 for wet condition. These RMR values after treatment with adjustment factors give SMR as 32 for dry and 24 for wet conditions. Using these values, cohesion and angle of internal friction for the slide zone are $0.167 \mathrm{MPa}$ and $20.68^{\circ}$ respectively.

Hence, the intersection of joints, slope angle and angle of internal friction are $50^{\circ}, 55^{\circ}$ and $20.68^{\circ}$ respectively and are fulfilling the condition of wedge failure that intersection of two joint planes must be less than the inclination of slope face but more than the friction angle of slope material $(\phi)$. Therefore predicting wedge type of failure for Aglar North slide. A circle corresponding to the angle of internal friction has also been drawn on the stereonet that shows the instability zone. Density $(\gamma)$ of exposed rock is determined to be $2.76 \mathrm{gm} / \mathrm{cc}$. For the calculation of factor of safety, stereonet (Fig. 9b) determines graphically all input parameters required (Table 8). The factor of safety thus calculated is 2.05 in dry and 1.3 in wet conditions indicating stability of slope under existing conditions.

s slide is situated at $1 \mathrm{~km}$ from the Aglar Bridge towards Nainbag on National Highway 507, in NW of the Aglar River (Fig. 5b). Located on fairly steep slope of $45^{\circ}$ in $220^{\circ} \mathrm{SW}$ direction, the zone of detachment of slide has maximum length and width of $70 \mathrm{~m}$ and $50 \mathrm{~m}$ respectively while, its zone of transportation is approximately $140 \mathrm{~m}$ in length and $30 \mathrm{~m}$ in width. Along the road, the slide is affecting a distance of about $90 \mathrm{~m}$ (Fig. 6b). The exposed rock in the area is brownish quartzites of the Nagthat Formation with strike $\mathrm{N} 80^{\circ} \mathrm{W}-\mathrm{S} 80^{\circ} \mathrm{E}$ and dip of $50^{\circ}-55^{\circ}$ towards $\mathrm{N} 10^{\circ} \mathrm{E}$.

Three sets of joints are observed having strike $\mathrm{N} 70^{\circ} \mathrm{E}$ $\mathrm{S} 70^{\circ} \mathrm{W}$ dip of $45^{\circ}$ due $\mathrm{N} 20^{\circ} \mathrm{W}$; strike $\mathrm{N} 74^{\circ} \mathrm{W}-\mathrm{S} 74^{\circ} \mathrm{E}$ dip of $50^{\circ}$ due $\mathrm{S} 16^{\circ} \mathrm{W}$; strike $\mathrm{N} 86^{\circ} \mathrm{E}-\mathrm{S} 86^{\circ} \mathrm{W}$ dip of $63^{\circ}$ due S. All the joints and slope data is plotted in stereonet for deducing the resultant discontinuity pattern. It is observed that joints J2 and J3 along with the slope are responsible for the failure (Fig. 9a).

Joints are spaced with average spacing of $0.14 \mathrm{~m}$ and are slightly rough. Using joint orientation, spacing parameters from the field, RQD (53\%), and UCS (138 MPa) values, RMR is determined to be 68 for dry condition and 60 for wet condition. These RMR values after treatment with adjustment factors give SMR as 32 for dry and 24 for wet conditions. Using these values, cohesion and angle of internal friction for the slide zone are $0.167 \mathrm{MPa}$ and $20.68^{\circ}$ respectively.

Hence, the intersection of joints, slope angle and angle of internal friction are $50^{\circ}, 55^{\circ}$ and $20.68^{\circ}$ respectively and are fulfilling the condition of wedge failure that intersection of two joint planes must be less than the inclination of slope face but more than the friction angle of slope material $(\phi)$. Therefore predicting wedge type of failure for Aglar North slide. A circle corresponding to the angle of internal friction has also been drawn on the stereonet that shows the instability zone. Density $(\gamma)$ of exposed rock is determined to be $2.76 \mathrm{gm} / \mathrm{cc}$. For the calculation of factor of safety, stereonet (Fig. 9b) determines graphically all input parameters required (Table 8). The factor of safety thus calculated is 2.05 in dry and 1.3 in wet conditions indicating stability of slope under existing conditions.

\section{Aglar Bridge Slide}

Aglar Bridge Slide is situated near Aglar Bridge on National Highway-507 to the left bank of Aglar River (Fig. 5c). Starting at the elevation of $820 \mathrm{~m}$, it extends down to the road level at $735 \mathrm{~m}$ above msl. Small 
(a)

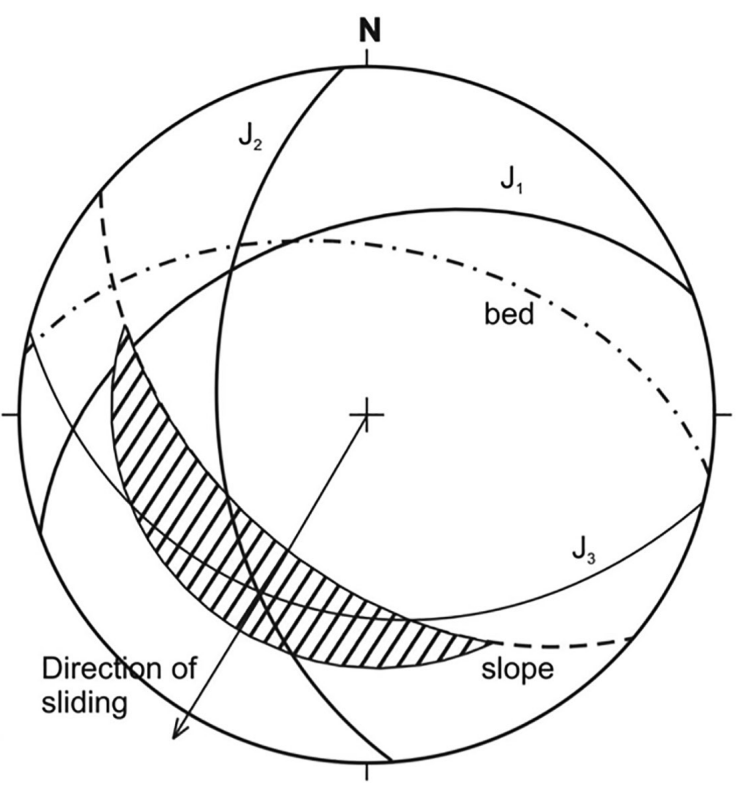

(b)

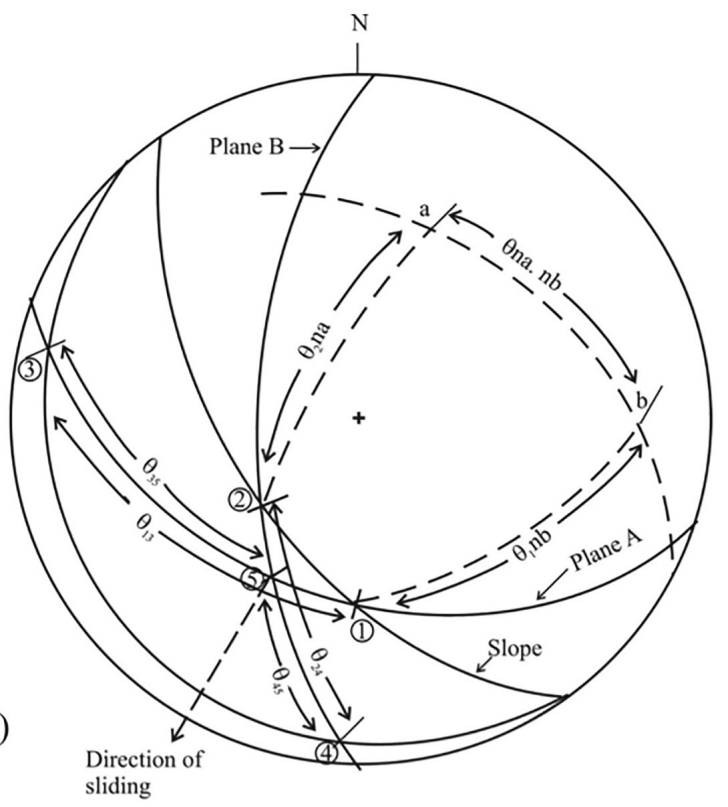

Fig. 9: (a) Stereoplot of Aglar North slide showing the probable direction of failure. Shaded region representing the potentially unstable zone, is formed by great circle of the slope and circle of the angle of internal friction; (b) Stereoplot for determination of input parameters for calculation of Factor of Safety of Aglar North Slide forming wedge geometry pertaining to the two discontinuity planes A and B (Dotted lines are geometrical measurements done to estimate angles between different points).

bushes and shrubs are observed on the left side of about $87 \mathrm{~m}$ failure surface (Fig. 6c).

The rock type present in this area are quartzite of the Nagthat Formation which are highly weathered showing reddish tinge and having an orientation as strike of $\mathrm{N} 80^{\circ} \mathrm{W}-\mathrm{S} 80^{\circ} \mathrm{E}$, dip of $37^{\circ}-40^{\circ}$ towards $\mathrm{N} 10^{\circ} \mathrm{E}$. Slope of the hill is steep showing $60^{\circ}$ angles in the direction of $550^{\circ} \mathrm{W}$.

Quartzites show 3 sets of joints having different orientation viz. strike $\mathrm{N} 80^{\circ} \mathrm{E}-\mathrm{S} 80^{\circ} \mathrm{W}$, dip of $50^{\circ}$ due $\mathrm{N} 10^{\circ} \mathrm{W}$; strike $\mathrm{N} 70^{\circ} \mathrm{W}-\mathrm{S} 70^{\circ} \mathrm{E}$ with dip of $48^{\circ}$ due $\mathrm{S} 20^{\circ} \mathrm{W}$; strike NS with dip of $67^{\circ}$ due N273 . All the joints and slope data are plotted in stereonet showing the resultant discontinuity pattern in which it is observed that joints $\mathrm{J} 1$ and $\mathrm{J} 3$ along with the slope is responsible for the instability of slide. Shaded portion, formed by great circle of slope and circle of angle of internal friction, represents the potential zone of instability (Fig. 10a). Joints are spaced with average spacing of $0.14 \mathrm{~m}$ and are slightly rough. RQD value is $53 \%$ and compressive strength measured is $75 \mathrm{MPa}$. These parameters estimate RMR as 63 and 55 for dry and wet conditions respectively and assign rock mass in good to fair class but considering joint patterns and their relation with slope, it is treated with adjustment factors that give SMR values as 21 for dry condition and 13 for wet condition. This causes the reduction in rock mass quality and slope is predicted to be unstable. Thereby, cohesion and angle of internal friction for this slide zone are $0.110 \mathrm{MPa}$ and $15.35^{\circ}$ respectively. Hence, the intersection of joints, slope angle and angle of internal friction $(\phi)$ are $47^{\circ}, 60^{\circ}$ and $15.35^{\circ}$ respectively and are fulfilling the condition of wedge failure.

Stereonet shown in Figure 10b determines graphically all input parameters required for the calculation of factor of safety. The calculated values factor of safety (Table 8) in dry condition is showing nearly stable condition but high instability during rains. Increased pore water pressure along the joints in heavy rainfall coupled with factors as high degree of weathering, fragile lithology, predominance of steep slope and higher relief can trigger the slide.

\section{Raira slide}

The slide is located on the left bank of Yamuna River, $1 \mathrm{~km}$ away from Judo towards Lakhwar Dam colony in the north of Raira village (Fig. 5d). The slide having failure surface $95 \mathrm{~m}$ long and $30 \mathrm{~m}$ wide started from the elevation of $820 \mathrm{~m}$ while the road is crossing the slide at the elevation of $660 \mathrm{~m}$ (Fig. 6d). Being on the bank of Yamuna River, the toe of the slide is actively eroded by turbulent river. Hill slope is $58^{\circ}$ in $\mathrm{N} 5^{\circ} \mathrm{W}$ direction. The vegetation is sparse along the road and almost whole zone is unstable and is affected by debris movement. This slide gets active mainly during rainy season and even damaged the 65 $\mathrm{m}$ long retaining wall, which completely blocked the road in 2008. Highly jointed and fractured quartzite beds upto 50 to $70 \mathrm{~cm}$ thick and reddish in color is having a strike $\mathrm{N} 60^{\circ} \mathrm{W}-\mathrm{S} 60^{\circ} \mathrm{E}$ and dip of $53^{\circ}$ towards $\mathrm{N} 30^{\circ} \mathrm{E}$. The joints present are not filled, having strike $\mathrm{N} 55^{\circ} \mathrm{E}-\mathrm{S} 55^{\circ} \mathrm{W}$ dip of $20^{\circ}$ due $\mathrm{N} 35^{\circ} \mathrm{W}$; EW dipping $52^{\circ}$ due $\mathrm{W}$ and $\mathrm{N} 52^{\circ} \mathrm{E}-\mathrm{S} 52^{\circ} \mathrm{W}$ dip of $69^{\circ}$ towards $\mathrm{S} 38^{\circ} \mathrm{E}$. 

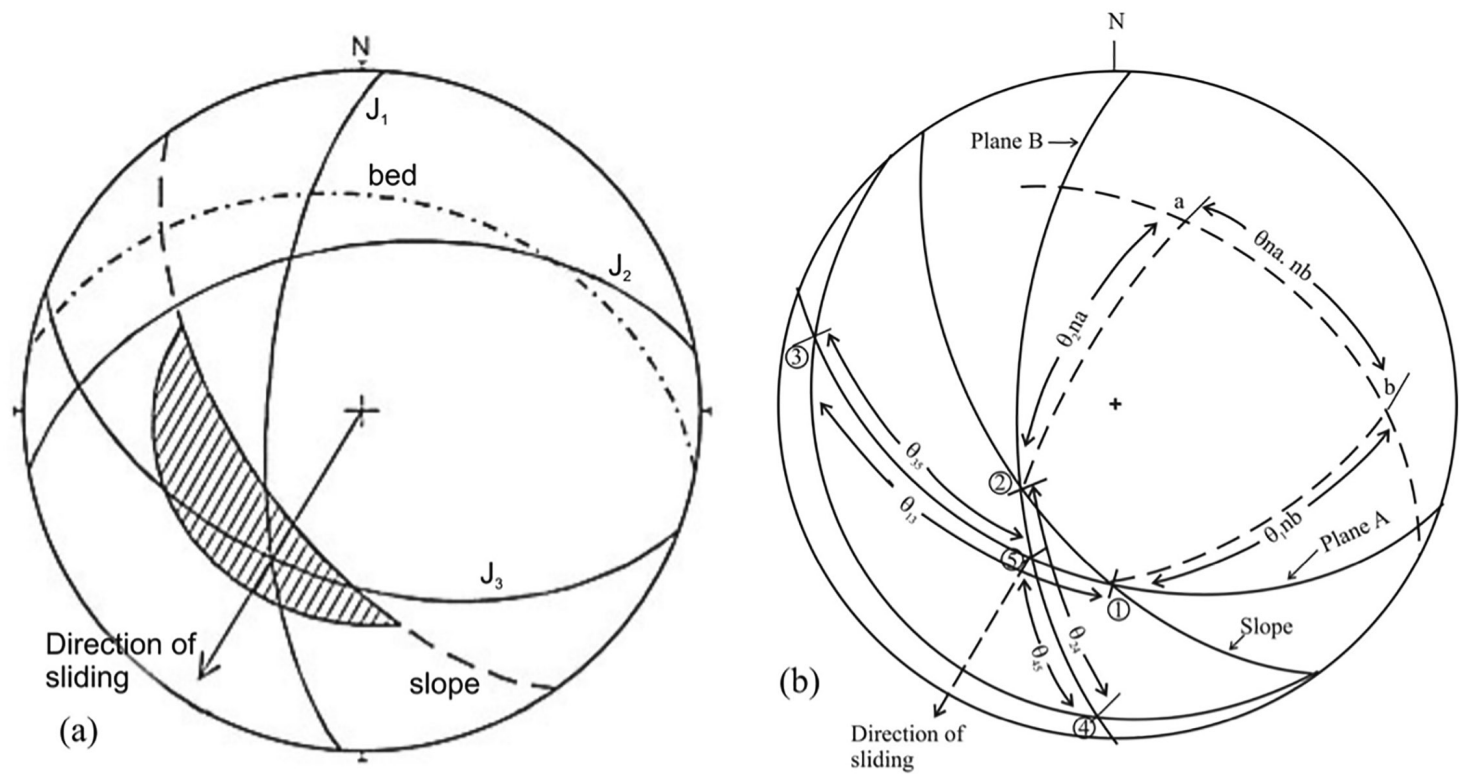

Fig.10: (a) Stereo plot of Aglar Bridge slide showing the probable direction of failure and shaded region represents potentially unstable zone. (b) Stereo plot for determination of input parameters for calculation of Factor of Safety of Aglar Bridge Slide forming wedge geometry pertaining to the two discontinuity planes A and B (Dotted lines are geometrical measurements done to estimate angles between different points).
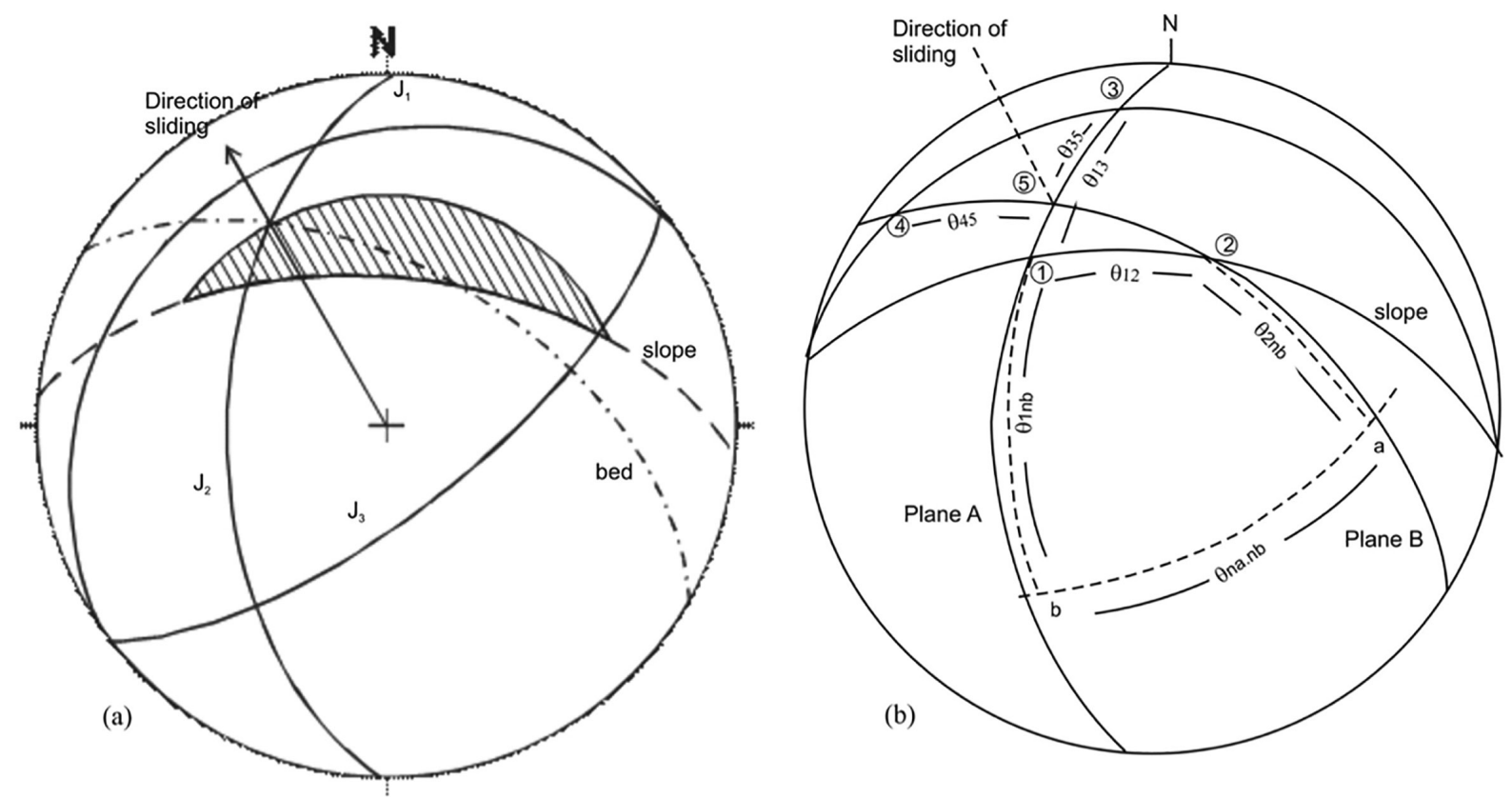

Fig. 11: (a) Stereoplot of Raira slide showing the probable direction of failure and shaded region represents potentially unstable zone. (b) Stereoplot for determination of input parameters for calculation of Factor of Safety of Raira Slide forming wedge geometry pertaining to the two discontinuity planes A and B. (Dotted lines are geometrical measurements done to estimate angles between different points).

All the joints and slope data are plotted in stereonet that shows that orientation of joint $\mathrm{J} 2$ and bed are acting as responsible discontinuities for this failure (Fig. 11a, 11b). Joints are spaced with average spacing of 0.17 $\mathrm{m}$ and are slightly rough giving RQD 57\% and the average compressive strength of quartzite estimated by UCS is $94 \mathrm{MPa}$. The RMR is determined as 63 and SMR calculated is 56.7 for dry and 48.5 for wet conditions assigning normal class to rock mass and partially unstable condition for slope.
RMR and SMR values were then used to estimate cohesion and angle of internal friction for the slide zone, which are $0.300 \mathrm{MPa}$ and $33.1^{\circ}$ respectively. The condition for wedge failure that is satisfied as intersection of joints, slope angle and angle of internal friction are $34^{\circ}, 58^{\circ}$ and $33.1^{\circ}$ respectively.

The value of factor of safety, as calculated is $>1$ (Table 8 ) indicating that slide is stable under present existing condition. 
Table 8: Input parameters and Factor of safety (F) of planar and wedge failure zones in dry and wet conditions.

\begin{tabular}{|c|c|c|c|}
\hline Slide & Input data & Formulas used & Result \\
\hline \multirow{6}{*}{$\begin{array}{l}\text { Lakhwar } \\
\text { Dam Axis }\end{array}$} & \multirow{6}{*}{$\begin{array}{l}\Psi_{\mathrm{f}}=60^{\circ} \\
\Psi_{\mathrm{p}}=50^{\circ} \\
\phi_{\mathrm{A}}=19^{\circ} \\
\gamma_{\mathrm{A}}=2.87 \mathrm{gm} / \mathrm{cm}^{3} \\
\gamma_{\mathrm{W}}=1 \mathrm{gm} / \mathrm{cm}^{3} \\
\mathrm{C}_{\mathrm{A}}=0.146 \mathrm{MPa} \\
\mathrm{C}_{\mathrm{B}}=0.104 \mathrm{MPa} \\
\phi_{B}=15^{\circ} \\
\gamma_{\mathrm{B}}=2.87 \mathrm{gm} / \mathrm{cm}^{3} \\
\mathrm{H}=70 \mathrm{~m}\end{array}$} & \multicolumn{2}{|l|}{ For dry condition } \\
\hline & & $\begin{array}{l}\underline{Z}=1-\left(\cot \Psi_{f} \cdot \tan \Psi_{p}\right) \\
A=(H-z) \operatorname{cosec} \Psi_{p} \\
W=\frac{1}{3} \gamma H^{2 *}\left(1-\frac{z^{2}}{H}\right)^{*} \cot \Psi_{p}-\cot \Psi_{f}\end{array}$ & $\begin{array}{l}z=22 \mathrm{~m}, \\
A=62.47 \\
W=12.66^{*} 10^{5} \mathrm{~kg}\end{array}$ \\
\hline & & $\mathrm{F}=\frac{\mathrm{c} \cdot \mathrm{A}+\mathrm{W} \cdot \cos \Psi_{\mathrm{p}} \tan \phi}{\mathrm{W} \cdot \sin \Psi_{\mathrm{p}}}$ & $\mathrm{F}=1.2$ \\
\hline & & \multicolumn{2}{|l|}{ For wet condition } \\
\hline & & $\begin{array}{l}Z_{w}=0.5^{\star} Z \\
V=\frac{1}{2} \gamma_{w} Z_{w}^{2} \\
U=\frac{1}{2} \gamma_{w} \cdot Z_{w}(H-Z) \operatorname{cosec} \Psi_{p}\end{array}$ & $\begin{array}{l}Z_{\mathrm{w}}=11 \mathrm{~m} \\
V=60500 \mathrm{~kg} / \mathrm{m} \\
U=343200 \mathrm{~kg} / \mathrm{m}\end{array}$ \\
\hline & & $\mathrm{F}=\frac{\mathrm{c} \cdot \mathrm{A}+\left(\mathrm{W} \cdot \cos \Psi_{\mathrm{p}}-U-V \sin \Psi_{\mathrm{p}}\right) \tan \phi}{\mathrm{W} \cdot \sin \Psi_{\mathrm{p}}}$ & $F=0.75$ \\
\hline \multirow[t]{7}{*}{$\begin{array}{l}\text { Aglar North } \\
\text { Slide }\end{array}$} & $\begin{array}{l}\Psi_{a}=50^{\circ} \\
\Psi_{b}=64^{\circ} \\
\Psi_{5}=50^{\circ} \\
\theta_{\text {na.nb }}=62^{\circ}\end{array}$ & $\begin{array}{l}\mathrm{A}=\frac{\cos \Psi_{\mathrm{a}}-\cos \Psi_{\mathrm{b}} \cdot \cos \theta_{\text {na.nb }}}{\sin \Psi_{5 . \sin ^{2} \theta_{\text {na.nb }}}} \\
\mathrm{B}=\frac{\cos \Psi_{\mathrm{b}}-\cos \Psi_{\mathrm{a} \cdot \cos \theta_{\text {na.nb }}}}{\sin \Psi_{5} \sin ^{2} \theta_{\text {na.nb. }}}\end{array}$ & $\begin{array}{l}A=0.732 \\
B=0.229\end{array}$ \\
\hline & $\begin{array}{l}\theta_{24}=78^{\circ} \\
\theta_{45}=47^{\circ} \\
\theta_{2 . n a}=64^{\circ}\end{array}$ & $X=\frac{\sin \theta_{24}}{\sin \theta_{45 . \cos \theta_{2 . n a}}}$ & $X=3.051$ \\
\hline & $\begin{array}{l}\theta_{13}=112^{\circ} \\
\theta_{35}=68^{\circ} \\
\theta_{1 . n b}=52^{\circ}\end{array}$ & $Y=\frac{\sin \theta_{13}}{\sin \theta_{35 . \cos } \theta_{1 . \mathrm{nb}}}$ & $Y=1.624$ \\
\hline & \multicolumn{3}{|l|}{ For dry condition } \\
\hline & $\begin{array}{l}\phi_{A}=20.68^{\circ} \\
\phi_{B}=20.68^{\circ} \\
\gamma=2.76 \mathrm{gm} / \mathrm{cm}^{3} \\
\gamma_{W}=0 \\
C_{A}=0.167 \mathrm{MPa} \\
C_{B}=0.167 \mathrm{MPa} \\
H=50 \mathrm{~m}\end{array}$ & 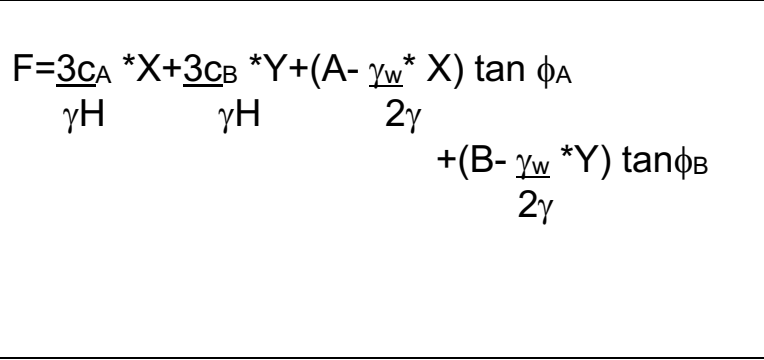 & $F=2.05$ \\
\hline & \multicolumn{3}{|l|}{ For wet condition } \\
\hline & $\begin{array}{l}\phi_{A}=16.91^{\circ} \\
\phi_{B}=16.91^{\circ} \\
\gamma=2.78 \mathrm{gm} / \mathrm{cm}^{3} \\
\gamma_{\mathrm{W}}=1 \\
C_{A}=0.125 \mathrm{MPa} \\
C_{B}=0.125 \mathrm{MPa} \\
H=50 \mathrm{~m}\end{array}$ & $\begin{aligned} & F=\frac{3 C_{A}}{\gamma H} * X+\frac{3 C_{B}}{\gamma H} * Y+\left(A-\frac{\gamma_{W}}{2 \gamma} X\right) \tan \phi_{A} \\
&+\left(B-\frac{\gamma_{W}}{2 \gamma}{ }^{*} Y\right) \tan \phi B\end{aligned}$ & $F=1.3$ \\
\hline
\end{tabular}




\begin{tabular}{|c|c|c|c|}
\hline Slide & Input data & Formulas used & Result \\
\hline \multirow[t]{7}{*}{$\begin{array}{l}\text { Aglar Bridge } \\
\text { Slide }\end{array}$} & $\begin{array}{l}\Psi_{a}=48^{\circ} \\
\Psi_{b}=67^{\circ} \\
\Psi_{5}=47^{\circ} \\
\theta_{\text {na.nb }}=64^{\circ}\end{array}$ & $\begin{array}{l}\mathrm{A}=\frac{\cos \Psi_{a}-\cos \Psi_{b} \cdot \cos \theta_{\text {na.nb }}}{\sin \Psi_{5 .} \sin ^{2} \theta_{\text {na.nb }}} \\
\mathrm{B}=\frac{\cos \Psi_{b}-\cos \Psi_{a} \cdot \cos \theta_{\text {na.nb }}}{\sin \Psi_{5} \sin ^{2} \theta_{\text {na.nb. }}}\end{array}$ & $\begin{array}{l}A=0.84 \\
B=0.165\end{array}$ \\
\hline & $\begin{array}{l}\theta_{24}=74^{\circ} \\
\theta_{45}=46^{\circ} \\
\theta_{2 . n a}=69^{\circ}\end{array}$ & $X=\frac{\sin \theta_{24}}{\sin \theta_{45 . \cos \theta_{2 . n a}}}$ & $X=3.34$ \\
\hline & $\begin{array}{l}\theta_{13}=106^{\circ} \\
\theta_{35}=76^{\circ} \\
\theta_{1 . \mathrm{nb}}=62^{\circ}\end{array}$ & $Y=\frac{\sin \theta_{13}}{\sin \theta_{35 . \cos \theta_{1 . n b}}}$ & $\mathrm{Y}=1.96$ \\
\hline & \multicolumn{3}{|l|}{ For dry condition } \\
\hline & $\begin{array}{l}\phi_{A}=15.35^{\circ} \\
\phi_{B}=15.35^{\circ} \\
\gamma=2.69 \mathrm{gm} / \mathrm{cm}^{3} \\
C_{A}=0.110 \mathrm{MPa} \\
C_{B}=0.110 \mathrm{MPa} \\
H=75 \mathrm{~m}\end{array}$ & 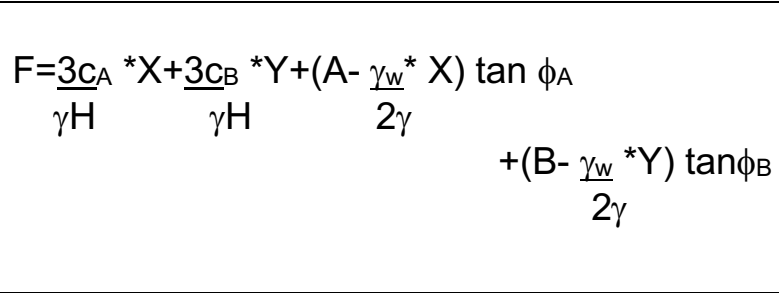 & $F=1.14$ \\
\hline & \multicolumn{3}{|l|}{ For wet condition } \\
\hline & $\begin{array}{l}\phi_{A}=11.52^{\circ} \\
\phi_{B}=11.52^{\circ} \\
\gamma=2.7 \mathrm{gm} / \mathrm{cm}^{3} \\
C_{A}=0.067 \mathrm{MPa} \\
C_{B}=0.067 \mathrm{MPa}\end{array}$ & $\begin{aligned} F=\frac{3 C_{A}}{\gamma H}{ }^{*} X+\frac{3 C_{B}}{\gamma H}{ }^{*} Y+\left(A-\frac{\gamma_{w}{ }^{*}}{2 \gamma} X\right) & \tan \phi_{A} \\
& +\left(B-\frac{\gamma_{W}}{2 \gamma} Y\right) \tan \phi_{B}\end{aligned}$ & $F=0.56$ \\
\hline \multirow[t]{7}{*}{ Raira Slide } & $\begin{array}{l}\Psi_{a}=54^{\circ} \\
\Psi_{b}=52^{\circ} \\
\Psi_{5}=34^{\circ} \\
\theta_{\text {na.nb }}=88^{\circ}\end{array}$ & $\begin{array}{l}\mathrm{A}=\frac{\cos \Psi_{\mathrm{a}}-\cos \Psi_{b} \cdot \cos \theta_{\text {na.nb }}}{\sin \Psi_{5} \sin ^{2} \theta_{\text {na.nb }}} \\
\mathrm{B}=\frac{\cos \Psi_{\mathrm{b}-\cos \Psi_{a} \cdot \cos \theta_{\text {na.nb }}}}{\sin \Psi_{5} \sin ^{2} \theta_{\text {na.nb. }}}\end{array}$ & $\begin{array}{l}A=1.041 \\
B=1.094\end{array}$ \\
\hline & $\begin{array}{l}\theta_{24}=72^{\circ} \\
\theta_{45}=38^{\circ} \\
\theta_{2 . n a}=56^{\circ}\end{array}$ & $X=\frac{\sin \theta_{24}}{\sin \theta_{45 . \cos } \theta_{2 . n a}}$ & $X=2.763$ \\
\hline & $\begin{array}{l}\theta_{13}=42^{\circ} \\
\theta_{35}=28^{\circ} \\
\theta_{1 . \mathrm{nb}}=80^{\circ}\end{array}$ & $Y=\frac{\sin \theta_{13}}{\sin \theta_{35 \cdot \cos \theta_{1 . n b}}}$ & $Y=8.208$ \\
\hline & \multicolumn{3}{|l|}{ For dry condition } \\
\hline & $\begin{array}{l}\phi_{A}=33.1^{\circ} \\
\phi_{B}=33.1^{\circ} \\
\gamma=2.71 \mathrm{gm} / \mathrm{cm}^{3} \\
\mathrm{C}_{\mathrm{A}}=0.300 \mathrm{MPa} \\
\mathrm{C}_{\mathrm{B}}=0.300 \mathrm{MPa} \\
\mathrm{H}=80 \mathrm{~m}\end{array}$ & $\begin{aligned} \mathrm{F}=\frac{3 \mathrm{C}_{\mathrm{A}}}{\gamma \mathrm{H}}{ }^{*} \mathrm{X}+\underline{\mathrm{C}}_{\mathrm{B}}{ }^{*} \mathrm{H}+\left(\mathrm{A}-\frac{\gamma_{\mathrm{W}}{ }^{*}}{2 \gamma} \mathrm{X}\right) \tan \phi_{\mathrm{A}} & \\
& +\left(\mathrm{B}-\frac{\gamma_{\mathrm{W}}}{2 \gamma}{ }^{*} \mathrm{Y}\right) \tan \phi_{\mathrm{B}}\end{aligned}$ & $F=5.9$ \\
\hline & \multicolumn{3}{|l|}{ For wet condition } \\
\hline & $\begin{array}{l}\phi_{A}=29^{\circ} \\
\phi_{B}=29^{\circ} \\
\gamma=2.73 \mathrm{gm} / \mathrm{cm}^{3} \\
C_{A}=0.254 \mathrm{MPa} \\
C_{B}=0.25 \mathrm{MPa} \\
\mathrm{H}=80 \mathrm{~m}\end{array}$ & $\begin{aligned} \mathrm{F}=\frac{3 \mathrm{C}_{\mathrm{A}}}{\gamma \mathrm{H}} & \mathrm{X}^{*}+\frac{3 \mathrm{C}_{B}}{\gamma \mathrm{H}}{ }^{*} \mathrm{Y}+\left(\mathrm{A}-\frac{\gamma_{\mathrm{w}}{ }^{*}}{2 \gamma} \mathrm{X}\right) \tan \phi \mathrm{A} \\
& +\left(\mathrm{B}-\frac{\gamma_{\mathrm{w}}}{2 \gamma} \mathrm{Y}\right) \tan \phi \mathrm{B}\end{aligned}$ & $\mathrm{F}=3.9$ \\
\hline
\end{tabular}




\section{CONCLUSIONS}

Slope stability assessment, empirically by slope mass classification system and analytically by limit equilibrium method is well in agreement with each other. The field situation is reasonably depicted in kinematic analysis.

These translational hazardous slide zones are present in close proximity with Aglar fault and borderlines of competent and incompetent beds. During construction, likely weakness planes as joints, faults etc. get exposed and their geometry, orientation, interrelation with slope gets disturbed from prevailing equilibrium making the slope vulnerable for failure. Strength of rock mass, being fair as predicted by rock mass rating, alone is incapable to cause any failure, instead its association with structure and unfavorable interrelationship with slope may have initiated the instability. Saturated conditions influenced the stability significantly as indicated by the declining Factor of Safety (FS) with an increasing saturation.

Raira slide has a normal rock mass that has $40 \%$ probability of failure in both dry and wet conditions, thq5 also verified analytically by FS to be above 1 and at present, it is stable. Aglar North slide has rock mass with unstable conditions of $60 \%$ failure probability. Though stable in dry conditions, it tends to fail in saturated conditions, hence should be re-excavated or provided with the anchored wall. Both Lakhwar Dam Slide and Aglar Bridge slide are completely unstable in wet conditions, which have $90 \%$ probability of failure. These slides need priority mitigation measures and should be protected from excessive water contact, seepage during rainfall and during the impoundment of reservoir, as FS is below unity in saturated conditions. Management of the surface and subsurface water is the most efficient stabilization measures for these slide zones. The direct impact of the intense rainfall and runoff causing excessive erosion should be attended by sealing joints and fractures either by grouting or by rock bolt anchoring. Along the hillside of roads, drainage channels can be constructed to capture and drain excessive water. Since, road construction and expansion are necessary, maintaining the slope surface in combination with surface and subsurface drainage and provision of retaining structures, as gabion wall, breast wall etc need to be prioritized. Geofabric reinforcement with steel grids or rock netting or reinforced concrete of these slides can be effectively use as mitigation measures. Bioengineering works involving plantation of vegetation having high binding effects, jute coring and netting are essential in the upper and middle part of the slides. All these methods in combination with each other, bearing in mind the stability analysis, can effectively protect the unstable slopes.

\section{AUTHOR'S CONTRIBUTION}

S.P. Bhatta proposed the current research, conducted fieldwork for structural and lithological observations, collected samples and prepared the figures as well. D. Dudeja analyzed the geotechnical parameters in laboratory, processed and interpreted the data. Whole work was done under the guidance of A.K. Biyani.

\section{ACKNOWLEDGEMENTS}

The authors are grateful to the Department of Science and Technology, Government of India for financial support to D. Dudeja under WOS-A scheme.

\section{REFERENCES}

Abbas, S.M., Konietzky, H., 2015, Rock Mass Classification Systems, Konietzky, H. (ed), TU Bergakademie Freiberg, Germany, 51p.

Abramson, L., Thomas, L., Sharma, S., Boyce, G.M., 1996, Slope stability and stabilization methods, Wiley, Hoboken, 738p.

Ahmad, M., Umrao, R.K., Ansari, M.K., Singh, R., Singh, T.N., 2013, Assessment of rock fall hazard along the road cut slopes of state highway-72, Maharashtra, India. Geo materials, 3(1); pp15-23.

Ambrosi, C., Crosta, G.B., 2006, Large sacking along major tectonic features in the central Italian Alps, Engineering Geology, 83 (1-3); pp183-200.

Anbalagan, R., 1997, Mass wasting types, causes and mapping in himalayan region, In: Agarwal DK, Krishna AP, Joshi V, Kumar K, Palni MS (eds) Perspectives of mountain risk engineering in the himalayan region. Gyanodaya Publications, Nainital; pp 33-52.

Anbalagan, R., Sharma, S., Raghuvanshi, T.K., 1992, Rock mass stability evaluation using modified SMR approach. In: Proceedings of 6th natural symposium on rock mechanics, Bangalore, India; pp 258-268.

Anbalagan, R., Singh, B., Chakraborty, D., Kohli, A., 2007, A field manual for landslide investigations Report submitted to Department of Science and Technology, New Delhi.

Anbalagan, R., Kohli, A., Chakraborty, D., 2008, Geotechnical evaluation of Harmony landslide on Karnaprayag, Gwaldam road, Uttarakhand Himalaya, Current Science, 94(12); pp 1613-1619.

Bareither, C.A., Edil, T.B., Benson, C.H., Mickelson, D.M., 2008, Geological and physical factors affecting the friction angle of compacted sands Journal of Geotechnical and Geo environmental Engineering, 134(10); pp1476-1489.

Bieniawski, Z.T., 1979, Rock mass classification in rock engineering. In: Bieniawski ZT (ed) Exploration for rock engineering, proceedings of the symposium expl. Rock Engineering, Johannesburg, pp 97-106.

Brideau, M.A., Stead, D., Couture, R., 2006, The structural 
and engineering geology of the East Gate Landslide, Purcell Mountains, British Columbia, Canada Engineering Geology, 84 (3-4); pp183-206.

Bureau of Indian Standard,1998a, IS: 13365 (Part 1), Quantitative classification systems of rock mass guidelines - rock mass rating (RMR) for predicting engineering properties, BIS, New Delhi.

Carrara, A., Cardinali, M., Detti, R., Guzzetti, F., Pasqui, N., Reichenba, P., 1991, GIS technique and statistical models in evaluating landslide hazard, Earth Surface process land, 16; pp 427-445.

Chand, J.B., 2011, A GIS Based Systematical Model For Slope Failure Hazard Assessment, unpublished thesis submitted to Kyushu University, Fukuoka, Japan.

Chung, C.F., Fabbri, A.G., 1995, Multivariate regression analysis for landslide hazard zonation, In: Carrara A, Guzzetti F (eds) Geographical information systems in assessing natural hazards. Kluwer Academic Publisher, Dordrecht, pp107-142.

Deere, D.U., 1964, Technical description of rock cores for engineering purposes, Rock Mechanics and Engineering Geology, 1(1); pp 17-22.

Dudeja, D., Bhatt, S.P., Biyani, A.K., 2017, Stability assessment of slide zones in Lesser Himalayan part of Yamunotri pilgrimage route, Uttarakhand, India, Environmental Earth Sciences, 76(1); pp 1-18.

Eid, H.T., 2014, Stability charts for uniform slopes in soils with nonlinear failure envelopes, Engineering Geology, 168; pp. 38-45.

Ermini, L., Catani, F., Casagli, N., 2005, Artificial neural networks applied to landslide susceptibility assessment, Geomorphology, 66; pp 327-343.

Gorbushina, V.K., 1997 Effect of landslide processes on construction and operation of hydropower structures, Hydrotech Construction, 31(10); pp. 629-634.

Gupta, S.S., Singh, R., Vishal, V., Singh, T.N., 2013, Detail investigation of stability of in-pit dump slope and its capacity optimization, International Journal of Earth Sciences and Engineering, 6(2); pp 146-159.

Hammouri, N.A., Abdallah, I., Malkawi, H., Yamin, M.A., 2008, Stability analysis of slopes using the finite element method and limiting equilibrium approach, Bulletin of Engineering Geology and Environment, 67; pp 471-478.

Harp, E.L., Wells, W.G. II., Sarmiento, J.G., 1990, Pore pressure response during failure in soils. Geological Society of America Bulletin, 102; pp 428-438.

Hoek, E., Bray, J.W., 1981, Rock slope engineering, Inst. of Mining and Metallurgy, London.

Iverson, R.M., 2000, Landslide triggering by rain infiltration, Water Resources Research, 36(7); pp 1897-1910.

Jade, S., Sarkar, S., 1993, Statistical models for slope instability classification, Engineering Geology, 36; pp 91-98.
Joshi, M., Rajan, P.P., 2018, Weathering Controlled Landslide in Deccan Traps: Insight from Mahabaleshwar, Maharashtra, Journal of the Geological Society of India, 92, pp.555-561.

Kanungo, D.P., Pain, A., Sharma, S., 2013, Finite element modelling approach to assess the stability of debris and rock slopes - a case study from the Indian Himalayas, Natural Hazards, 69 (1), pp 1-24.

Kumar, N., Verma, A.K., Sardana, S., Sarkar, K., Singh, T.N., 2017, Comparative analysis of limit equilibrium and numerical methods for prediction of a landslide, Bulletin of Engineering Geology and Environment,https://doi.org/10.1007/ s10064-0171183-4.

Li, X.Z., Xu, Q., 2016, Application of the SSPC method in the stability assessment of highway rock slopes in the Yunnan province of China, Bulletin of Engineering Geology and Environment, 75(2); pp 551-562.

Markland, J.T., 1972, A useful technique for estimating the stability of rock slopes when the rigid wedge sliding type of failure is expected., Imperial College Rock Mechanics Research Report, p19.

Milne, D., Hadjigeorgiou, J., Pakalnis, R., 1998, Rock mass characterization for underground hard rock mines, Tunn Undergr Space Technology,13(4); pp. 383-391.

Mondal, M.E.A., Siddique, T., Alam, M., 2016, Rock mass rating and kinematic analysis for slope stability investigation of Utari Dam in Lalitpur district of Uttar Pradesh, India, Journal of Geological Society of India, 87(4); pp 463-468.

Naithani, A.K., 2007, RMR- A system for characterizing rock mass classification: a case study from Garhwal Himalaya, Uttarakhand, Journal Geological Society of India, 70(4); pp 627-640.

Pain, A., Kanungo, D.P., Sarkar, S., 2014, Rock slope stability assessment using finite element based modelling - examples from the Indian Himalayas, Geomechanics and Geoengineering, 9(3); pp 21-30.

Palmstrom, A., 1982, The volumetric joint count - a useful and simple measure of the degree of jointing, In: Proceedings IV international congress IAEG, New Delhi, pp 221-228.

Pradhan, S.P., Vishal, V., Singh, T.N., 2011, Stability of slope in an open cast mine in Jharia coalfield, India slope mass rating approach, Mining Engineers Journal, 12(10); pp 36-40.

Pradhan, S.P., Vishal, V., Singh, T.N., Singh, V.K., 2014, Optimisation of dump slope geometry vis- à-vis flyash utilisation using numerical simulation, American Journal of Mining and Metallurgy, 2(1); pp 1-7.

Pradhan, S.P., Siddique, T., 2020, Stability assessment of landslide-prone road cut rock slopes in Himalayan terrain: a finite element method based approach, Journal of Rock Mechanics and Geotechnical Engineering, 12 (1), 59-73. 
Regmi, A.D., Cui, P., Dhital, M.R., Zou, Q., 2016, Rock fall hazard and risk assessment along Araniko Highway, Central Nepal Himalaya, Environmental Earth Sciences, 75; pp.1112.

Romana, M., 1985, New adjustment ratings for application of Bieniawski classification to slopes In proceedings of the international symposium on the role of rock mechanics in excavations for mining and civil works. International society of rock mechanics, Zacatecas, pp 49-53.

Romana, M., Toma's, R., Sero'n, J.B., 2015, Slope mass rating (SMR) geomechanics classification: thirty years review In: ISRM Congress 2015 proceedings - international symposium on rock mechanics, Quebec, Canada, pp10.

Reeuwijk, L.N., 1993, Procedures for Soil Analysis, International Soil Reference and Information Centre, pp 96.

Sarkar, K., Singh, T.N., Verma, A.K., 2012a, A numerical simulation of landslide-prone slope in Himalayan region - a case study, Arab Journal of Geosciences, 5; pp 73-81.

Sarkar, S., Kanungo, D.P., Kumar, S., 2012b, Rock mass classification and slope stability assessment of road cut slopes in Garhwal Himalaya, India, Geotechnical and Geological Engineering, 30(4); pp 827-840.

Shen, J., Karakus, M., Xu, C., 2013, Chart-based slope stability assessment using the Generalized HoekBrown criterion, International Journal of Rock Mechanics and Mineral Sciences, 64; pp 210-219.

Siddique, T., 2018, Stability and sensitivity analysis of Himalayan Road cut debris slopes: an investigation along NH-58 India, Natural Hazards, DOI: 10.1007/ s11069-018-3317-9.

Singh, J.L., Tamrakar, N.K., 2017, Slope mass rating around Malekhu- Thopal Khola corridor, Malekhu Central Nepal Lesser Himalaya, American Journal Science Engineering Technology, 2(1); pp 6-14.

Singh, R., Umrao, R.K., Singh, T.N., 2014, Stability evaluation of road-cut slopes in the Lesser Himalaya of Uttarakhand, India: Conventional and numerical approaches, Bulletin Engineering Geology and Environment, DOI 10.1007/s10064-013-0532-1.

Singh, A., Pal, S., Kanungo, D.P., 2020, An Integrated
Approach for Landslide Susceptibility-VulnerabilityRisk Assessment of Building Infrastructures in Hilly Regions of India, Environment Development and Sustainability, DOI: 10.1007/s10668-020-00804-z.

Singh, B., Goel, R.K., 1999, Rock mass classification: a practical approach in civil engineering, Elsevier.

Springman, S.M., Thielen, A., Kienzler, P., Friedel, S., 2013, A long-term field study for the investigation of rainfall-induced landslides, Geotechnique, 14; pp 1177-1193.

Taherniya, M.H., Mohammadi, M., Ajalloeian, R., 2014, Assessment of slope instability and risk analysis of road cut slopes in Lashotor Pass. Iran, Journal of Geological Research; pp.1-12.

Times of India, 2021, Landslide, not glacier, led to flash flood in Rishiganga river: IIRS report, February,9, http://timesofindia.indiatimes.com/articleshow.

Umrao, R.K., Singh, R., Ahmad, M., Singh, T.N., 2011, Stability analysis of cut slopes using continuous slope mass rating and kinematic analysis in Rudraprayag district, Uttarakhand, Geomaterials, 1(3); pp 79-87.

Valdiya, K.S., 1980, Geology of Kumaun Lesser Himalaya, Wadia Institute of Himalayan Geology, Dehradun.

Verma, A.K., Singh, T.N., Chauhan, N.K., Sarkar, K., 2016, A hybrid FEM-ANN approach for slope instability prediction, Journal of Instrumental Engineering (India), 97(3); pp171-180.

Vishal, V., Pradhan, S.P., Singh, T.N., 2015, Analysis of stability of slopes in Himalayan terrane along national highway109, India In: Engineering geology for society and territory, 1; pp 511-515.

Wieczorek, G.F., 1996, Landslide triggering mechanisms in: Turner AK, Schuster RL (eds) Landslides: investigation and mitigation, Transportation Research Board Special Report 247, National Research Council, Washington, pp 76-79.

Zhu, D.Y., Lee, C.F., Jiang, H.D., 2003, Generalised framework of limit equilibrium methods for slope stability analysis Geotechnique, 53(4); pp 377-395.

Zydroń, T., Zawisza, E., 2011, Shear strength investigation of soils of landslide areas, Geologija, 53(3); pp. $147-155$. 